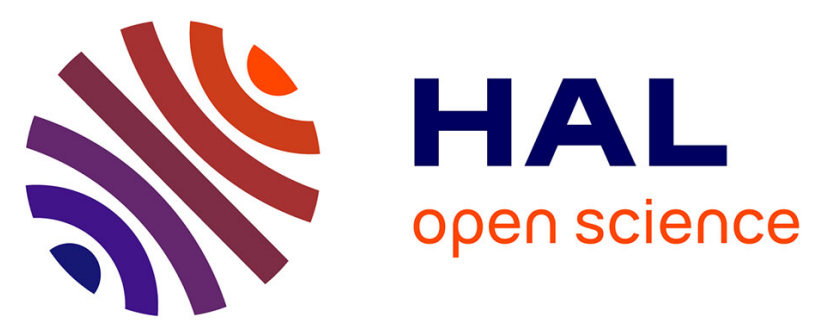

\title{
How do subduction processes contribute to forearc Andean uplift? Insights from numerical models
}

Joseph Martinod, Vincent Regard, Yoann Letourmy, Hadrien Henry, Riad Hassani, Sébastien Baratchart, Sébastien Carretier

\section{- To cite this version:}

Joseph Martinod, Vincent Regard, Yoann Letourmy, Hadrien Henry, Riad Hassani, et al.. How do subduction processes contribute to forearc Andean uplift? Insights from numerical models. Journal of Geodynamics, 2015, 96, pp.10.1016/j.jog.2015.04.001. 10.1016/j.jog.2015.04.001 . hal-01147947

\section{HAL Id: hal-01147947 \\ https://hal.science/hal-01147947}

Submitted on 3 May 2015

HAL is a multi-disciplinary open access archive for the deposit and dissemination of scientific research documents, whether they are published or not. The documents may come from teaching and research institutions in France or abroad, or from public or private research centers.
L'archive ouverte pluridisciplinaire HAL, est destinée au dépôt et à la diffusion de documents scientifiques de niveau recherche, publiés ou non, émanant des établissements d'enseignement et de recherche français ou étrangers, des laboratoires publics ou privés. 


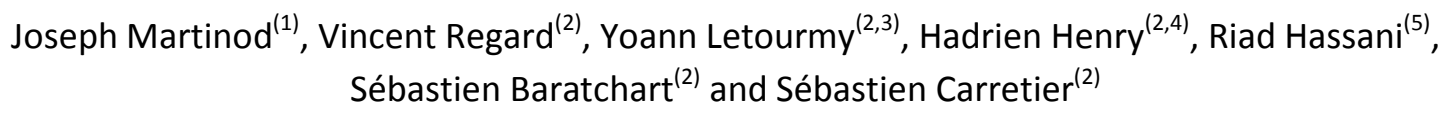

(1) Corresponding author; ISTerre, UMR CNRS-IRD-Université de Savoie, 73376 Le Bourget du Lac cedex, France (joseph.martinod@univ-savoie.fr). Tel (+33) 475798710

(2) GET, UMR CNRS-IRD-Université de Toulouse, 14 avenue Edouard Belin, 31400 Toulouse, France

(3) Department of Geology, Baylor University, One Bear Place \#97354, Waco, TX 76798, USA

(4) ARC CCFS \& GEMOC, Department of Earth and Planetary Sciences, Macquarie University, Sydney, NSW 2109, Australia

(5) Géoazur, UMR CNRS-IRD-Université de Nice Sophia-Antipolis, 250 rue A. Einstein, 06560 Valbonne, France

Abstract: We present numerical models to study how changes in the process of subduction may explain the observed Quaternary uplift of the Andean forearc region. Indeed, most segments of the South American Pacific coasts between 16 and $32^{\circ} \mathrm{S}$ have been uplifting since the Lower Pleistocene, following a period of stability of the forearc region. Models confirm that local uplift is expected to occur above ridges, this phenomenon being predominant in central Peru where the Nazca Ridge is subducting. We investigate the effects of slab pull, interplate friction and convergence velocity on the vertical displacements of the overriding plate. We propose that the global tendency to coastal uplift is accompanying the deceleration of the Nazca-South America convergence that occurred in the Pleistocene. In contrast, forearc subsidence may accompany increasing convergence velocities, as suggested by the subsidence history of the South America active margin.

Key-words: Andes, subduction, forearc, uplift, modeling 


\section{Introduction}

It is well known since Darwin (1846) that segments of the Pacific coasts of South America are rapidly uplifting. Although obscured by rapid short-term vertical displacements resulting from the seismic cycle, long-term (at geological time-scales) coastal uplift is evidenced by well preserved paleoshores, some of them being perched several hundred meters above sea-level. Many of these paleoshores have been dated using different techniques (cosmogenic isotopes, U-Th, ESR and Aminoacid racemization on shells, $\mathrm{Sr}$ isotopes...). Available ages show that most of the preserved paleoshores are younger than $1 \mathrm{Myr}$ and formed during highstand periods (e.g., Leonard \& Wehmiller, 1992; Saillard et al., 2010). Since the global sea level did not reach elevations higher than $10 \mathrm{~m}$ above the present-day sea level during the last Myr, most of the present-day elevation of Pacific South American paleoshores results from tectonic uplift of the coastal area (e.g., Pedoja et al., 2011). Recently, Regard et al. (2010) noted that uplifted paleoshore remnants are preserved along the entire coastal segment of the Central Andes between 16 and $30^{\circ} \mathrm{S}$, including along shore segments in northern Chile where the ocean is erosive and in which most of the coast corresponds to a several hundred meters-high cliff interrupting the Coastal Cordillera. Regard et al. (2010) concludes that South America, along a $2000 \mathrm{~km}$-long coastal segment corresponding to the Central Andes, has been uplifting since the Middle Pleistocene. Rodriguez et al. (2013) observe the same coastal evolution between 30 and $32^{\circ} \mathrm{S}$. In fact, Fuenzalida et al. (1965) had already noted that Chilean Coasts North of $40^{\circ} \mathrm{S}$ have been uplifting during the Pleistocene. These authors note that this Quaternary renewal of coastal uplift contrasts with the stability and/or subsidence that prevailed before the Middle Pleistocene (Fuenzalida et al., 1965 ; Paskoff, 1978 ; Clift \& Hartley, 2007; Rodriguez et al., 2013).

In this paper, we review the available information on present-day uplift at geological time scales $\left(10^{5}\right.$ to $10^{6}$ years), in order to constrain the causes that may explain it. Since the observed uplift is visible along $3000 \mathrm{~km}$ of coasts between $40^{\circ} \mathrm{S}$ and $16^{\circ} \mathrm{S}$, some causes responsible for the coastal vertical displacements must have a global origin resulting either from the dynamics of subduction, from the dynamics of plate convergence along the South American active margin, or from global changes that affect the interplate contact properties. We use a finite element model reproducing the subduction of the Nazca plate beneath South America, in order to see how geodynamical changes may control the vertical displacements of the overriding plate in the coastal area.

\section{Coastal uplift along the South American active margin}

Long-term uplift is visible along large segments of the Pacific coasts of South America. Pedoja et al. (2011) review the evidence of coastal uplift since the last interglacial stage, 122 kyrs ago (Marine isotopic Stage 5e). They note that along most of the coasts of western South America, paleoshores dated from the last interglacial period are generally located between 15 and 50 meters above the present-day sea level (Figure 1). Since the maximum sea level during the last interglacial period was between $3 \pm 1 \mathrm{~m}$ (Siddall et al., 2007) and 7.2 $\pm 1.3 \mathrm{~m}$ (Kopp et al., 2009) above the present-day sea level, it means that most of the coasts have been uplifting at rates generally larger than $0.1 \mathrm{~mm} / \mathrm{yr}$. Locally, the MIS-5e paleoshore has been observed at elevations higher than 60 meters above sea level, the corresponding uplift rate being larger than $0.4 \mathrm{~mm} / \mathrm{yr}$. Such rapid uplift rates, however, are generally restricted to particular sites located above the subduction of buoyant aseismic ridges and/or in places where active faults are deforming the coastal area (Figure 1). 


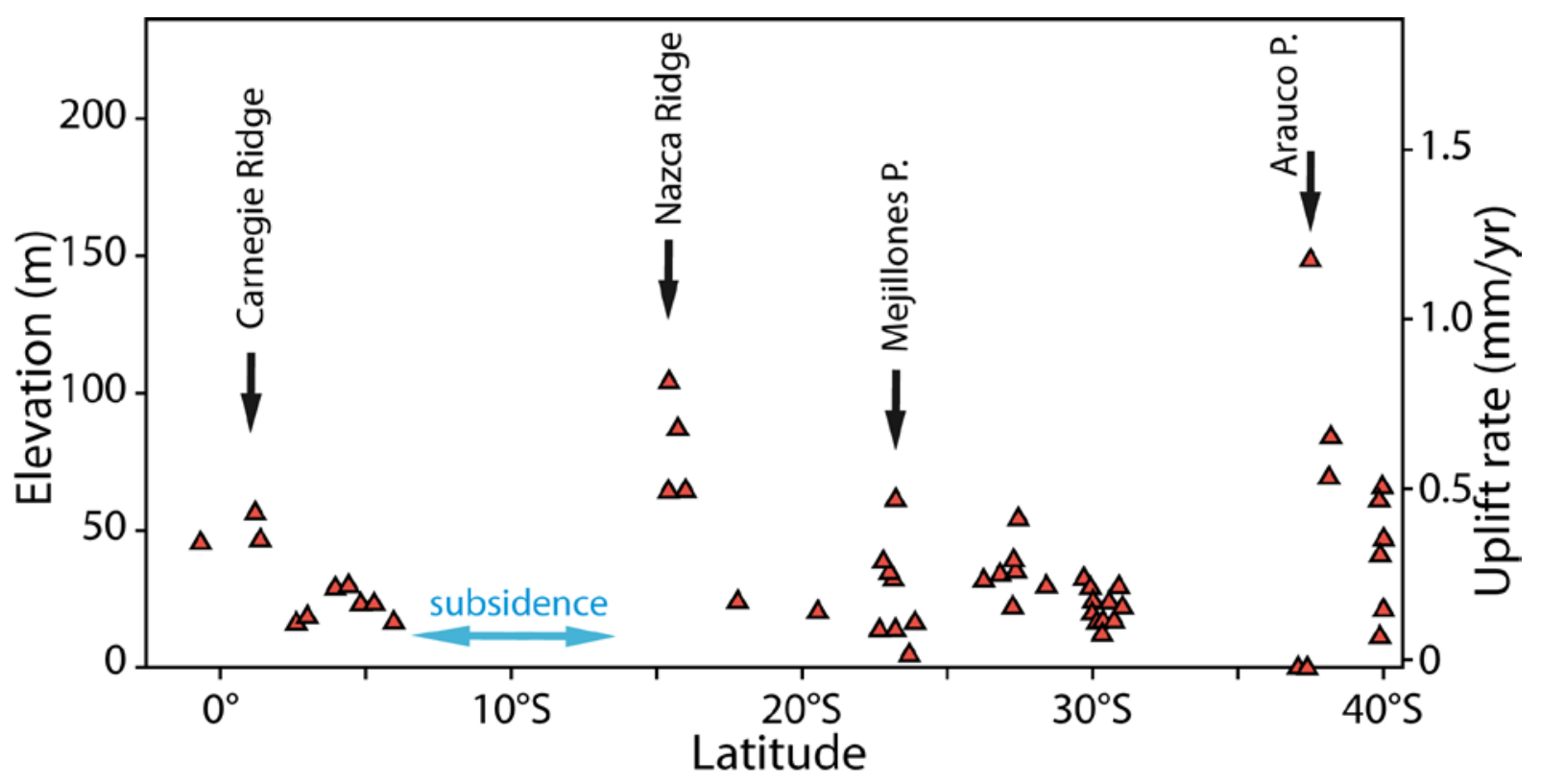

Figure 1: present-day elevation and average uplift rate of paleo-shores formed during the last interglacial period (marine isotopic stage 5e). Only dated terraces are reported here. After Pedoja et al. (2011), Regard et al. (2010), Melnick et al., (2009)

The Carnegie and Nazca ridges are the two largest aseismic ridges being subducted beneath South America. The Carnegie Ridge is subducting beneath Ecuador since at least 1.4 Myrs, but the proposed age for the onset of subduction is disputed and ranges from 1 to 15 Myrs (see Michaud et al., 2009, for review). This ridge being roughly parallel with the convergence direction, its locus of subduction beneath the continent should have remained relatively stable during the Quaternary, although some authors suspect it has been migrating southward from the Colombian coasts (Gutscher et al., 1999). In contrast, the Nazca Ridge is oblique with respect to the convergence azimuth. Its subduction beneath Peru migrated $500 \mathrm{~km}$ to the South-East during the last 10 Myrs (Hampel, 2002). Particularly rapid uplift rates are observed in Ecuador above the subducting Carnegie Ridge (Pedoja et al., 2006), and in Peru above the Nazca Ridge (Hsu, 1992; Goy et al., 1992; Macharé and Ortlieb, 1992; Wipf et al., 2008; Saillard et al., 2011). South of the Nazca ridge axis, ridge subduction increases the coastal uplift velocity. Indeed, the consequence of the southward migration of the ridge is that more buoyant segments of the ridge are progressively being subducted beneath that part of the continent. The effect of the ridge on coastal uplift is noticeable, from Atico $\left(16.2^{\circ} \mathrm{S}, 320 \mathrm{~km} \mathrm{SE}\right.$ of the ridge crest) to the ridge axis (Regard et al., 2010; Saillard et al., 2011). In contrast, north of the ridge axis, the Peruvian coast is subsiding because the ridge is progressively moving farther away to the south, explaining why Quaternary paleoshores are not visible onshore Central Peru. Paleocanyons filled by Quaternary deposits, for instance below the city of Lima (Le Roux et al., 2000), evidence subsidence in that part of the Pacific Coast.

Other ridges are being subducted beneath the continent (Iquique and Juan Fernandez Ridges, located at $21^{\circ}$ and $33^{\circ} \mathrm{S}$, respectively). The corresponding topographic anomalies, however, are much smaller and their effect on coastal uplift is not clear, despite the fact that the Juan Fernandez Ridge is suspected to be responsible for the appearance of a flat-slab segment beneath North-Central Chile (e.g., Yañez et al., 2001; Martinod et al., 2010). 
In contrast, the very rapid uplift rate reported by Melnick et al. (2009) in the Arauco Peninsula $\left(\sim 37.5^{\circ} \mathrm{S}\right)$ does not correspond to any subducting ridge. Melnick et al. (2009) show this uplift may result from N-S continental shortening resulting from the Northward motion of the Chiloe forearc sliver. In fact, it has been noted that peninsulas generally correspond to particular places in which crustal deformations result in larger uplift velocities. Another example of rapidly uplifting peninsula is Mejillones ( $23^{\circ} \mathrm{S}$, Ortlieb et al., 1996; Gonzalez et al., 2003). Larger uplift rate of peninsulas result from roughly trench-parallel faults that accommodate the relative uplift of the western blocks and whose activity may result from basal accretion processes (e.g., Delouis et al., 1998; Gonzalez et al., 2003; Melnick et al., 2006). This tectonic activity seems to be related with the segmentation of subduction mega-earthquakes (Delouis et al., 1998; Melnick et al., 2009; Victor et al., 2011; Métois et al., 2012; Cortes-Aranda et al., 2015).

Despite the upper plate tectonics and the uplift rates at geological timescales $\left(>10^{5}\right.$ years) share some common characteristics with mega-subduction earthquakes, the question of causal links between them remains open. The pattern of coseismic uplift during mega-earthquakes generally shows remarkable trench-distance dependence, with uplift close to the trench and subsidence inland of the earthquake rupture (Farias et al., 2010; Vigny et al., 2011). The analysis of worldwide MIS-5 shorelines also shows that long-term uplift depends on the distance to the trench (Henry et al., 2014). However, long-term uplift is observed both in zones where interseismic coupling is large (central Chile, northern Ecuador) or small (northern Peru) (Métois et al., 2012; Nocquet et al., 2014). Although rapidly uplifting peninsulas seem to correspond to zones of low interseismic coupling (Métois et al., 2012; Cortes-Aranda et al., 2015), coastal subsidence also occurs in central Peru, north of the Nazca ridge, where the interseismic coupling is particularly small (Nocquet et al., 2014). Then, there is no clear relationship between the interseismic behavior of the subduction channel and uplift of the coastal area.

Figure 1 shows that coastal uplift is restricted neither to areas located above subducting ridges, nor subject to active crustal deformations. Regard et al. (2010) suggest that uplift has been generalized since the Middle Pleistocene along the coasts of Central Andes, between 15 and $30^{\circ} \mathrm{S}$, which includes many areas where the oceanic floor does not present any noticeable topographic anomaly. Thus, although heterogeneities of the subducting plate may locally influence coastal uplift, other large-scale physical processes are uplifting the overriding plate at rates of $\sim 0.1-0.3 \mathrm{~mm} / \mathrm{yr}$. Processes occurring along coastal segments larger than $1000 \mathrm{~km}$ are probably related with plate tectonics and the dynamics of subduction. In this paper, we use a finite element code to look at the effects on coastal uplift of changes in the parameters controlling the process of subduction.

\section{Mechanical modeling}

We use the finite element code Adeli to model the subduction of an oceanic plate beneath an advancing continent. This code belongs to the FLAC family of codes (Cundall, 1988; Poliakov and Podlachikov, 1992) and is based on the Dynamic Relaxation Method. Adeli has been used in numerous geodynamical applications, for processes at crustal (e.g., Vanbrabant et al., 1999; Got et al., 2008) as well as at lithospheric scale (Lesne et al., 2000; Neves et al., 2008). The reader interested by the numerical method used in this code may consult Hassani et al. (1997) or Chery et al. (2001) for details. 
The modeling approach adopted here is close to that presented in Gibert et al. (2012): the model consists in two visco-elastic plates whose horizontal convergence velocity is imposed by lateral boundary conditions (Figure 2). Parameters of the numerical models are given in Table 1 . The overriding continental plate is $100 \mathrm{~km}$-thick, including a $30 \mathrm{~km}$-thick buoyant crust. The subducting oceanic plate is not homogeneous, in order to observe how changing the nature of the subducting plate triggers vertical displacements of the overriding plate. In the reference model, the oceanic lithosphere is $80 \mathrm{~km}$-thick, with a $10 \mathrm{~km}$-thick crust. The density of mantle lithosphere and oceanic crust is $3.3 \mathrm{~g} / \mathrm{cm}^{3}$ and $2.9 \mathrm{~g} / \mathrm{cm}^{3}$, respectively. That of the asthenosphere being $3.23 \mathrm{~g} / \mathrm{cm}^{3}$, the buoyancy of the subducting plate is negative, except when we model the subduction of a thick plateau beneath the continental plate.

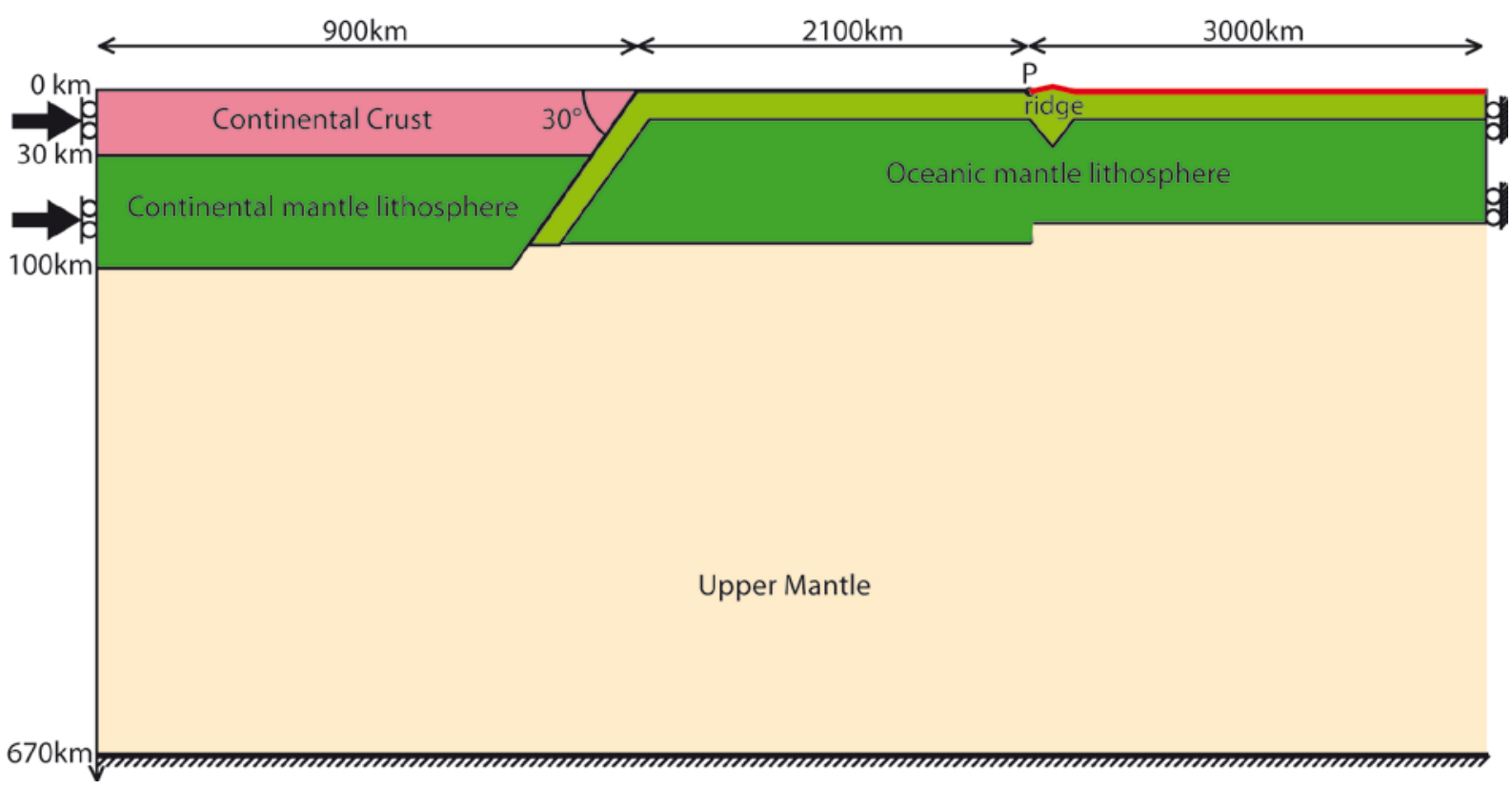

Figure 2: Initial experimental setup: lateral boundary conditions impose convergence and subduction of the oceanic plate beneath the continent. When point $P$ reaches the trench, the subduction has become stationary. Depending on the experiment, the convergence velocity, interplate friction, or subducting plate buoyancy changes following the subduction of this point (see Table 1). This figure represents both the ridge that subducts in experiment RIDGE, the thinning of the lithosphere on the right side of point $P$ (experiment AGE-25), and the surface of the oceanic plate marked in red corresponds to the segment of oceanic lithosphere for which the interplate friction changes (experiments FRIC-O and FRIC-6)

As in Gibert et al. (2012), the viscosity of the upper mantle is neglected, i.e., the interaction of the asthenosphere on the lithosphere reduces to a hydrostatic pressure acting in each part of the lithosphere boundary in contact with the fluid. Gibert et al. (2012) show that numerical models built using this set-up reproduce analogue experiments presented in Guillaume et al. (2009), in which the ratio between the upper plate and upper mantle viscosity is large $\left(\eta_{\downarrow} / \eta_{a} \sim 5000\right)$. In fact, most authors now consider that the viscosity ratio between lithosphere and the upper mantle is smaller, between 100 and 500 (Funiciello et al., 2008; Schellart, 2008; Ribe, 2010). We discuss below how neglecting the upper mantle viscosity may affect model results.

The 670-km deep discontinuity is modeled as an impassable rigid boundary, over which the slab remains anchored (no slip allowed). This assumption is justified considering that many slabs remain 
at least temporarily stalled at the 670-km discontinuity (e.g., van der Hilst et al., 1991; Faccenna et al., 2001). Moreover, several previous studies confirm that the direct penetration of the slab through the transition zone is inhibited if the timescale of the analyzed process is limited (order of few tens of million years) and if the viscosity increase at the upper-lower mantle boundary is at least one order of magnitude (Christensen, 1996; Funiciello et al., 2003). These studies show that for these time periods, the dynamics of the slab is correctly reproduced considering the upper-lower mantle discontinuity as a rigid boundary condition.

\begin{tabular}{|c|c|c|c|c|c|c|c|c|c|}
\hline \multicolumn{3}{|c|}{ Experiment } & Reference & VEL-40 & VEL-120 & FRIC-0 & FRIC-6 & AGE-25 & RIDGE \\
\hline \multirow{6}{*}{ 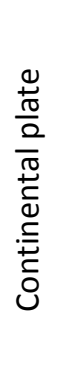 } & \multirow{3}{*}{ crust } & thickness (km) & 30 & 30 & 30 & 30 & 30 & 30 & 30 \\
\hline & & $\begin{array}{l}\text { density (kg.m- } \\
\text { 3) }\end{array}$ & 2800 & 2800 & 2800 & 2800 & 2800 & 2800 & 2800 \\
\hline & & viscosity (Pa.s) & $10^{24}$ & $10^{24}$ & $10^{24}$ & $10^{24}$ & $10^{24}$ & $10^{24}$ & $10^{24}$ \\
\hline & \multirow{3}{*}{ Mantle } & thickness (km) & 70 & 70 & 70 & 70 & 70 & 70 & 70 \\
\hline & & $\begin{array}{l}\text { density (kg.m- } \\
\text { 3) }\end{array}$ & 3300 & 3300 & 3300 & 3300 & 3300 & 3300 & 3300 \\
\hline & & viscosity (Pa.s) & $2 \times 10^{24}$ & $2 \times 10^{24}$ & $2 \times 10^{24}$ & $2 \times 10^{24}$ & $2 \times 10^{24}$ & $2 \times 10^{24}$ & $2 \times 10^{24}$ \\
\hline \multirow{6}{*}{ 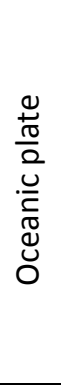 } & \multirow{3}{*}{ crust } & thickness (km) & 10 & 10 & 10 & 10 & 10 & 10 & $35^{*}$ \\
\hline & & $\begin{array}{l}\text { density (kg.m- } \\
\text { 3) }\end{array}$ & 2900 & 2900 & 2900 & 2900 & 2900 & 2900 & 2900 \\
\hline & & viscosity (Pa.s) & $2 \times 10^{24}$ & $2 \times 10^{24}$ & $2 \times 10^{24}$ & $2 \times 10^{24}$ & $2 \times 10^{24}$ & $2 \times 10^{24}$ & $2 \times 10^{24}$ \\
\hline & \multirow{3}{*}{ mantle } & thickness (km) & 70 & 70 & 70 & 70 & 70 & 50 & $45^{*}$ \\
\hline & & $\begin{array}{l}\text { density (kg.m- } \\
\text { 3) }\end{array}$ & 3300 & 3300 & 3300 & 3300 & 3300 & 3300 & 3300 \\
\hline & & viscosity (Pa.s) & $2 \times 10^{24}$ & $2 \times 10^{24}$ & $2 \times 10^{24}$ & $2 \times 10^{24}$ & $2 \times 10^{24}$ & $2 \times 10^{24}$ & $2 \times 10^{24}$ \\
\hline \multicolumn{3}{|c|}{ Convergence velocity (mm/yr) } & 80 & 40 & 120 & 80 & 80 & 80 & 80 \\
\hline \multicolumn{3}{|c|}{ Interplate friction } & 0,03 & 0,03 & 0,03 & 0 & 0,06 & 0,03 & 0,03 \\
\hline
\end{tabular}

Table 1: Characteristics of numerical experiments. Bold numbers mark parameters that change with respect to the reference experiment following the subduction of point $P$ (Figure 2). Stars mark a shortlived change in the numerical conditions (see the text for further explanations).

We also neglect thermal effects affecting the subducting plate. The age-depending thermal state of the oceanic plate is taken into account changing the thickness of the mantle lithosphere, which both modifies the strength and the buoyancy of the plate. Younger oceanic plates are hotter, thinner and also less rigid. Even if modeling the oceanic plate as a visco-elastic layer in which the viscosity does not vary with depth is a major simplification of the reality, the viscosity should be chosen proportional to the average stress difference $\left(\sigma_{1}-\sigma_{3}\right)$ between the surface and the base of the plate, necessary to deform the plate. However, rheological profiles deduced from laboratory experiments on the mechanical properties of rocks (e.g., Kohlstedt et al., 1995) show that the average stress ratio between younger and older lithosphere is equal or smaller than their thickness ratio. This corresponds to small variations, especially considering the very large uncertainties on the rheology of the lithosphere and the various phenomena that may modify it. Moreover, the force necessary to bend the lithosphere is proportional to $H^{3}$, where $H$ is the thickness of the plate (Funiciello et al., 2003). Then, we consider that the main consequences of the subduction of a younger slab segment arise from its smaller thickness and higher buoyancy, and that changing the thickness of the oceanic plate gives a first order approximation of the topographic changes that follow the subduction of a younger oceanic plate. Another limitation of these models is that we do not consider the rheological 
heterogeneity resulting from contrasted thermal regimes within the overriding plate (hot and weak volcanic arc vs. cold and rigid forearc region).

Using 2D numerical models implies that we reproduce cylindrical subduction zones in which changes in the properties of the subducting plate occur simultaneously along the entire trench. For instance, we are only able to model the effect of trench-parallel oriented subducting passive ridges. In these models, the upper mantle flow does not influence the dynamics of subduction since we neglect the upper mantle viscosity. In fact, 3D-experiments show that slab retreat requires toroidal mantle flow, and that this flow may severely slow down the motion of the trench for large slab width (Funiciello et al., 2006; Schellart et al., 2007; Guillaume et al., 2010). These experiments thus rather model narrow slabs in which trench motion is not opposed by mantle flow.
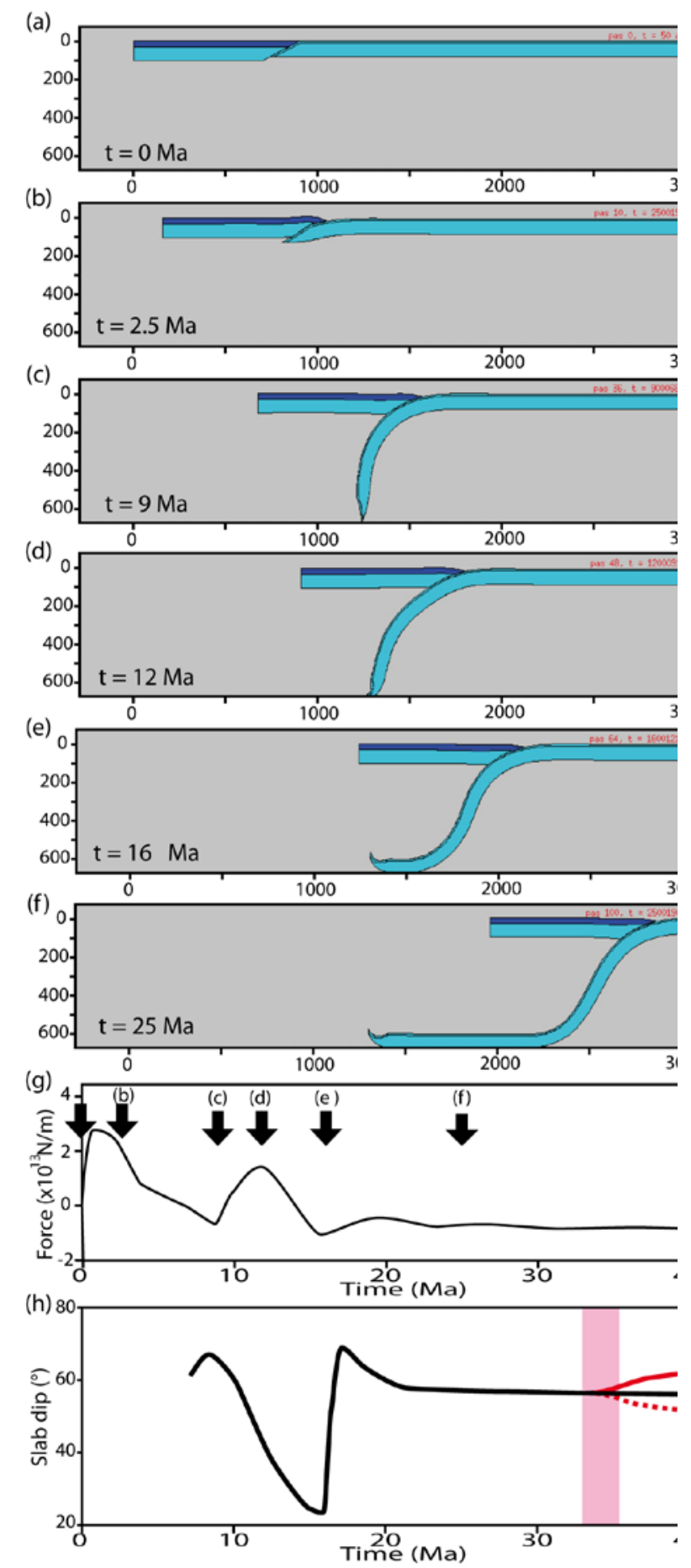

Figure 3: Evolution through time of the reference experiment. (a) to (f) show the slab geometry following $0,2.5,9,12,16$ and 25 Myrs of experiment. Only the left side of the numerical model is represented here, the right lateral edge of the subducting plate being located at $X=6000 \mathrm{~km}$. Steady subduction occurs following 23 Myrs of experiment. (g) Lateral boundary force applied on the continental plate to achieve convergence at constant $8 \mathrm{~cm} / \mathrm{yr}$ velocity. (h) Average dip of the slab calculated for depths between 150 and $350 \mathrm{~km}$, for the reference experiment (black line), experiments VEL-120 (increasing convergence velocity, red dotted line) and VEL40 (decreasing convergence velocity, red solid line). The pink vertical layer between 33 and 35.5 Myrs is the period during which the convergence velocity changes. 
The subducting plate is $5100 \mathrm{~km}$-long. The reference convergence velocity imposed by lateral boundary conditions is $80 \mathrm{~mm} / \mathrm{yr}$ (see Table 1), and experiments model an oceanic subduction that pursues for more than 60 Myrs.

Numerical experiments reproduce the typical evolution of the process of subduction observed in analogue experiments (Figure 3). A first transitory regime corresponds to the period necessary for the slab to interact with the upper-lower mantle $670 \mathrm{~km}$-deep discontinuity. This transitory regime has been observed in analogue experiments and described e.g. in Martinod et al. (2005) and Espurt et al. (2008). Figure $3 \mathrm{~g}$ shows the evolution of the horizontal force applied on the lateral boundary of the reference model (Model 1), necessary to achieve a constant convergence velocity. It also shows the average dip of the slab calculated for depths between 150 and $350 \mathrm{~km}$. Compression is necessary to initiate subduction. But as soon as subduction has begun, the slab pulls the overriding plate trenchward and favors tension. Tension increases with the length of the slab till the slab interacts with the 670-km deep discontinuity, following 9 Myrs of subduction. Slab interaction with this impassable boundary results in transient compression, and in the horizontalisation of the slab above the discontinuity. This horizontalisation is accompanied by a decrease of the intermediate depth dip of the slab (Figure 3h). Steady subduction occurs as soon as the slab has deposited horizontally on the impassable discontinuity: the dip of the slab and lateral boundary forces stabilize as long as experimental conditions remain unchanged (Figure 3). This occurs following $23 \mathrm{Myrs}$, and the overriding plate topography stabilizes during the steady-state period of subduction.

In this paper, we study the evolution of mature subduction zones that reached a steady-state. This approach differs from that presented in papers comparing the evolution of topography in different experiments during the initiation of subduction, following $200 \mathrm{~km}$ (Hampel \& Pfiffner, 2006) or $600 \mathrm{~km}$ (Bonnardot et al., 2008) of slip on the plate interface. We prefer focus on steady-state subduction experiments, considering that subduction beneath western South America is occurring at least since the beginning of the Jurassic (Coira et al., 1982), and that the Nazca/Farallon slab clearly reached the $670 \mathrm{~km}$-deep discontinuity (Liu et al., 2003). Moreover, numerical experiments show that the overriding plate topography varies considerably during the initiation of subduction because the slap pull force is highly variable (Figure $3 \mathrm{~g}$ ). Then, during subduction initiation, the intensity of uplift or subsidence essentially depends on the chosen amount of slip on the subduction interface. Once the subduction is steady, we introduce a perturbation in the process and quantify its effects on the overriding plate topography. Perturbations either correspond to changes in the convergence velocity, in the interplate friction along the subduction channel, or in the buoyancy of the subducting plate which modifies the slab pull force. In nature, slab buoyancy may vary because the age of the subducting ocean is changing, or because an oceanic plateau is entering the subduction zone. We investigate how changes of these parameters modify the overriding plate topography, in order to constrain the geodynamical processes that may explain the observed vertical displacements of the western coasts of South America. We compare the evolution of topography in the reference model whose evolution is presented in Figure 3, with that of models in which a perturbation modifies steady-subduction. 


\section{Results}

\subsection{Convergence velocity}

We compare the evolution of topography in the reference model with two other models in which the convergence velocity varies. In these models, the initial convergence velocity is $80 \mathrm{~mm} / \mathrm{yr}$ as in the reference model. We change the convergence velocity at 33 Myrs, i.e. 10 Myrs following the initiation of steady subduction. The convergence velocity increases linearly from $80 \mathrm{~mm} / \mathrm{yr}$ at 33 Myrs to $120 \mathrm{~mm} / \mathrm{yr}$ at $35.5 \mathrm{Myrs}$ in Model VEL-120. Afterwards, the convergence velocity is maintained at $120 \mathrm{~mm} / \mathrm{yr}$ till the end of experiment. In Model VEL-40, in constrast, the convergence velocity decreases linearly from $80 \mathrm{~mm} / \mathrm{yr}$ before $33 \mathrm{Myrs}$, to $40 \mathrm{~mm} / \mathrm{yr}$ after $35.5 \mathrm{Myrs}$. Figure $3 \mathrm{~h}$ shows the evolution of the dip of the slab in experiments. In the reference experiment, the dip of the slab remains approximately constant $\left(\sim 57^{\circ}\right)$. The dip of the slab increases $\left(\sim 64^{\circ}\right)$ when the convergence velocity diminishes, and decreases when convergence accelerates, as observed in analogue experiments by Espurt et al. (2008).

Figure 4 presents the evolution of the overriding plate topography with time: We compare the topography of the reference model with that of experiments VEL-120 and VEL-40. Before 33 Myrs, the convergence velocity being the same in all models, the topography is comparable. In model VEL120 , the increase in convergence velocity results in the subsidence of the overriding plate close to the trench. The subsiding area is $\sim 200 \mathrm{~km}$ wide, which approximately corresponds to the contact area between the subducting and overriding plates, i.e. the forearc region located between the trench and the asthenospheric corner. In contrast, the back-arc area uplifts as long as the convergence velocity is increasing. As soon as the convergence velocity stabilizes at $120 \mathrm{~mm} / \mathrm{yr}$, surrection stops in the back-arc region, whereas subsidence continues for several Myrs close to the trench. The maximum subsidence velocity in the forearc during velocity increase is $\sim 0.3 \mathrm{~mm} / \mathrm{yr} 100$ $\mathrm{km}$ from the trench. Back-arc uplift is almost as rapid during the period of velocity increase, but it stops as soon as the convergence velocity is stabilized at $120 \mathrm{~mm} / \mathrm{yr}$.
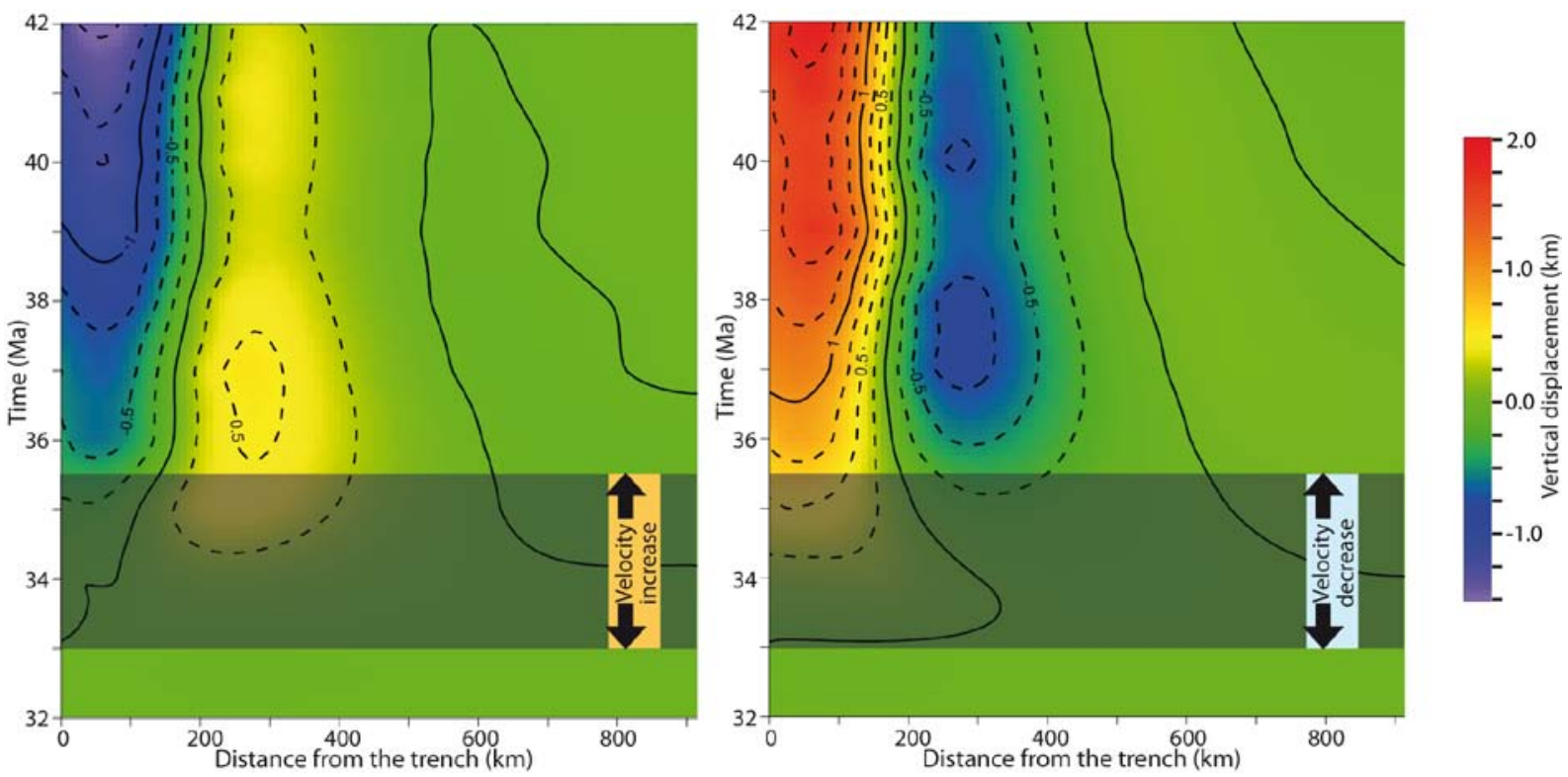

Figure 4: Vertical displacements vs. time in the overriding plate resulting from velocity increase (model VEL-120, left) or decrease (model VEL-40, right) 
Decreasing the convergence velocity results in the opposite vertical displacements pattern, i.e. uplift of the forearc region and subsidence in the back-arc area (Figure 4).

\subsection{Interplate friction}

Figure 5 shows the effect of varying the interplate friction along the subduction channel. In the reference model, the interplate friction coefficient is 0.03 and keeps constant during the entire experiment. This friction coefficient results in an average shear stress of $45 \mathrm{MPa}$ on the interplate fault zone, close to that estimated e.g. by Zhong \& Gurnis (1994) analyzing the topography of oceanic trenches. The corresponding interplate force is $\sim 4.10^{12} \mathrm{~N} / \mathrm{m}$, which corresponds to the value estimated by Husson (2012). In FRIC- 6 experiment, the friction coefficient between the subducting plate and the continent is also 0.03 below a point initially located at $X=3000 \mathrm{~km}$ on the subducting plate (point $P$ in Figure 2), and 0.06 above it. This point arrives at trench at 29.3 Myrs. Then, the interplate force progressively increases till the point reaches the asthenospheric corner. This occurs at 31.6 Myrs. Afterwards, the interplate friction is everywhere 0.06 along the subduction channel till the end of experiment. In FRIC-0 experiment, in contrast, the interplate friction drops from 0.03 to 0.00 following the subduction of point $P$.

Figure 5 presents the evolution of topography following an increase or decrease of the interplate friction. It shows that the short-term response to a modification of the interplate friction is different from the long-term one that pursues during several Myrs. The short-term response to an increase of the interplate friction, which increases the force component parallel to the subduction channel, is a downward deflection of the overriding plate. In contrast, decreasing the interplate friction first promotes continental uplift.

(a)

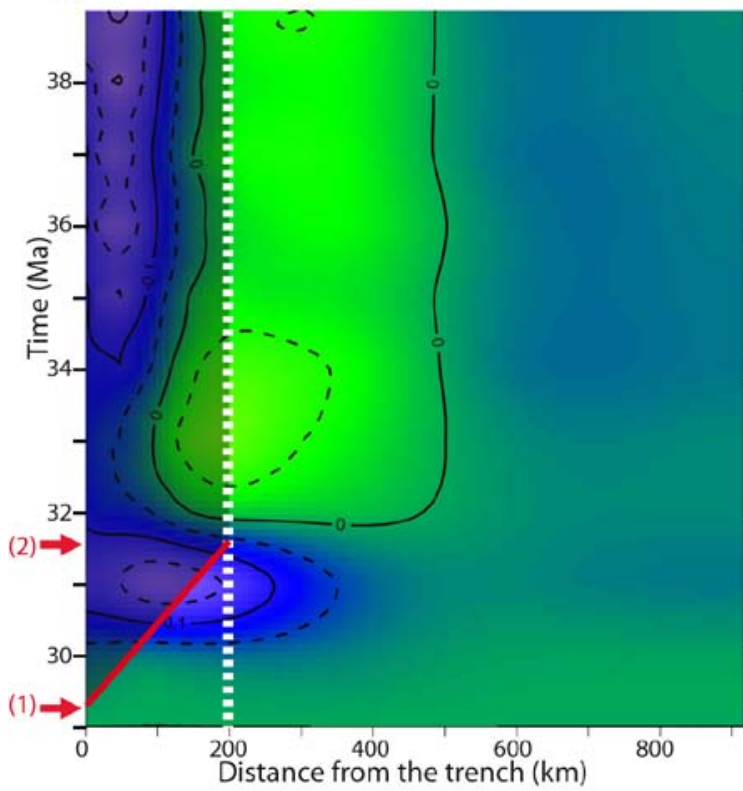

(b)

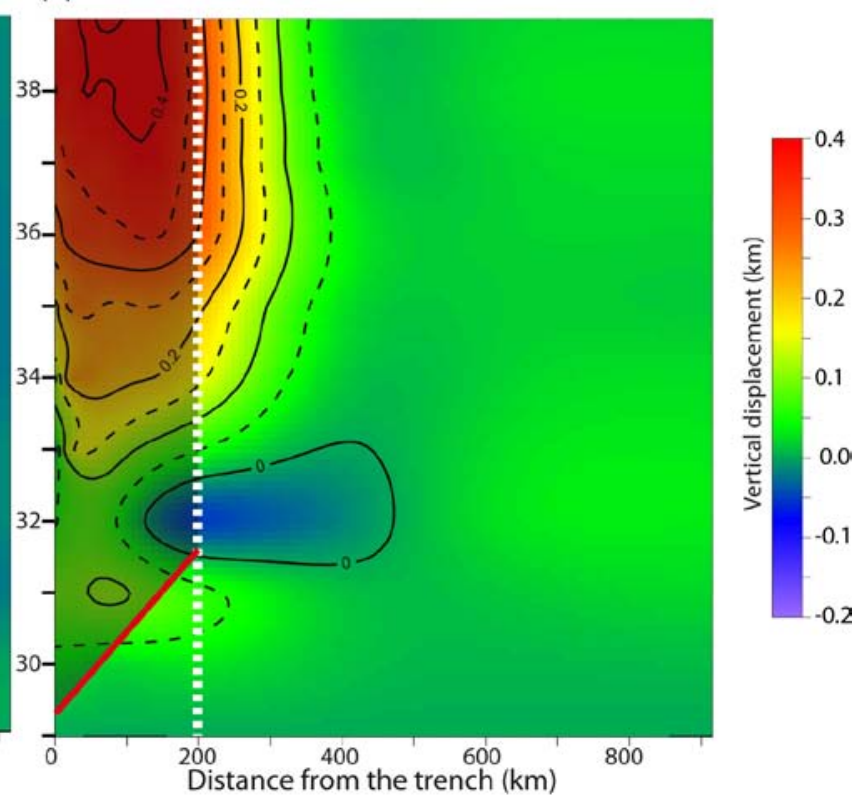

Figure 5: vertical displacements vs.time in the overriding plate resulting from increasing (a) or decreasing (b) interplate friction. The friction coefficient increases from 0.03 to 0.06 in (a), while it drops from 0.03 to 0 in (b). The white dotted line marks the position of the asthenospheric corner. The red line marks the position of the subducted point $P$ above which the interplate friction changes: in (1), point $P$ arrives at trench, in (2), it reaches the asthenosphere corner. 
Following this short-term response, larger interplate friction increases the flexure of the overriding plate, resulting in subsidence of the forearc region close to the trench and in uplift of the arc and back-arc area. In contrast, both the forearc and arc uplift following a decrease of the interplate force.

\subsection{Variation of the age of the subducting ocean}

Figure 6 presents the evolution of the overriding plate topography following a thinning of the subducting plate from 80 to $60 \mathrm{~km}$ (model AGE-25). In this model, the thickness of the oceanic mantle lithosphere decreases rapidly over a $100 \mathrm{~km}$ distance, while the oceanic crust thickness remains unchanged. In nature, such an abrupt diminution in the thickness of the oceanic lithosphere may reflect a diminution in the age of the oceanic floor from $\sim 45$ to $\sim 25$ Myrs (e.g., Cloos, 1993). This may occur for instance when a major transform fault separating contrasting sea-floor ages is subducted. Since the thickness of the oceanic crust is not changed, the average density of the plate decreases from 3.25 to $3.233 \mathrm{~g} / \mathrm{cm}^{3}$. In this model, the thinner lithosphere reaches the trench following 27 Myrs of subduction, and the asthenosphere corner 2.5 Myrs later. The thick lithosphere is entirely lying on the upper-lower mantle discontinuity after 37 Myrs.

The subduction of a younger oceanic plate results in a rapid uplift of the forearc area of the overriding plate. The back-arc area, in contrast, slightly subsides. This subsidence is the flexural response of the overriding plate to the smaller force oriented downwards that applies on the interplate contact area.
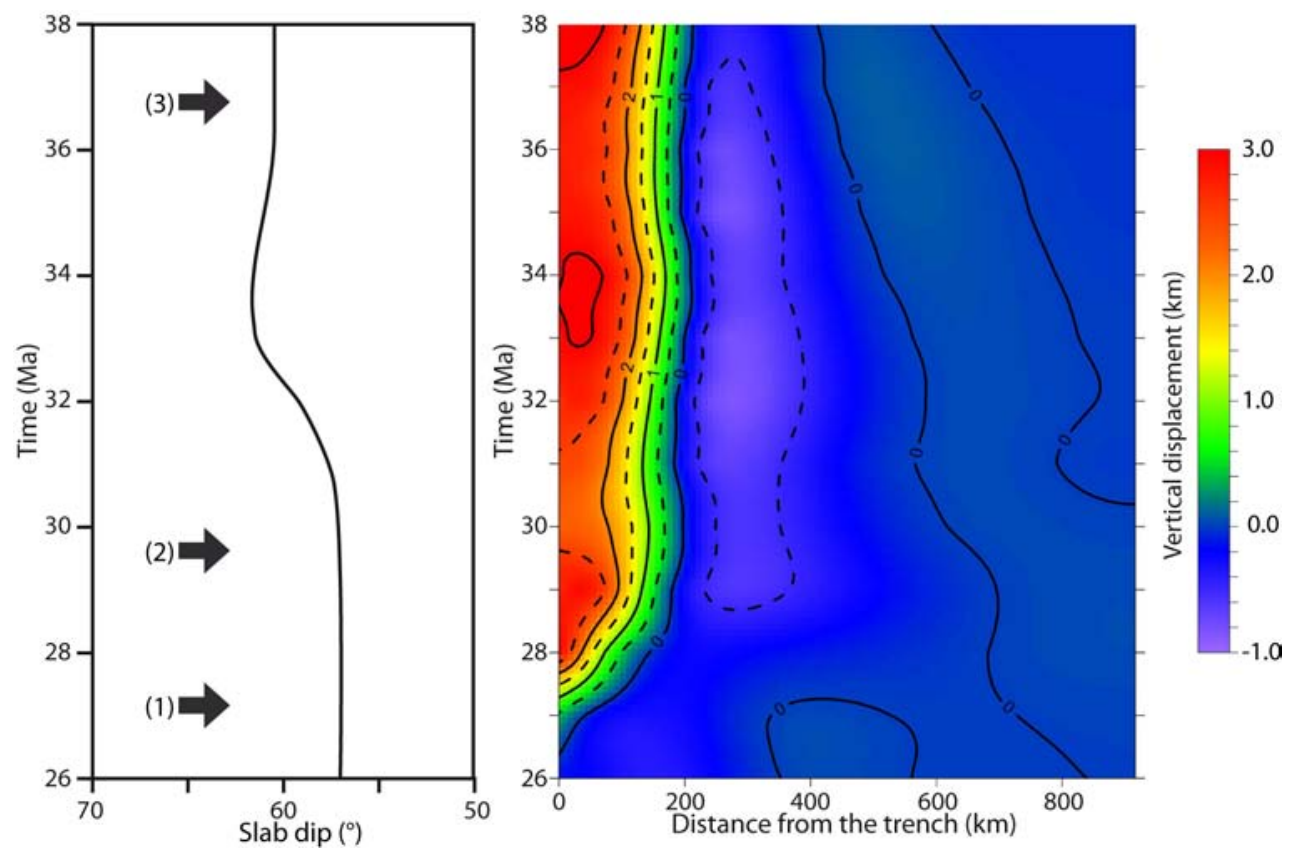

Figure 6: effects of a variation of the subduction seafloor age on the topography of the overriding plate. The oceanic plate that subducts beneath the continent during the beginning of this experiment is $80 \mathrm{~km}$ thick. (1) a thinner (60 km) oceanic plate enters the trench; (2) it reaches the asthenosphere corner; (3) the thick part of the plate is entirely lying on the $670 \mathrm{~km}$-deep discontinuity.

The younger part of the plate being less thick, the radius of curvature of the slab beneath the overriding plate decreases (e.g., Irvine \& Schellart, 2012), which explains the increasing dip of the slab following 30 Myrs (Figure 3h). This increase in the dip of the slab occurs after the thinner plate 
has reached the asthenosphere corner. Changing the geometry of the slab beneath the forearc area, indeed, would require deforming the upper plate, which cannot occur rapidly given the viscosity of the overriding continent. The younger plate negative buoyancy is smaller, which progressively diminishes the slab pull force as the older part of slab deposits above the 670-km deep boundary. Smaller slab-pull, in turn, explains the progressive diminution of the dip of the slab that occurs after 34 Myrs.

\subsection{Subduction of a bathymetric high}

We model the subduction of an oceanic plateau corresponding to a thicker oceanic crust isostatically balanced (model RIDGE, Figure 7). The maximum thickness of the crust is $35 \mathrm{~km}$, vs. 10 $\mathrm{km}$ elsewhere, which results in a topographic high $3 \mathrm{~km}$ above the rest of the oceanic plate. The width of the plateau is $200 \mathrm{~km}$, the thickness of the crust increasing linearly from the plateau edge to its centre. The volume of such a plateau is approximately that of the Nazca and Carnegie aseismic ridges that subduct beneath South America (Martinod et al., 2005). The main difference between these natural examples and these $2 \mathrm{D}$ numerical experiments is that we model here the subduction of a ridge parallel to the trench.

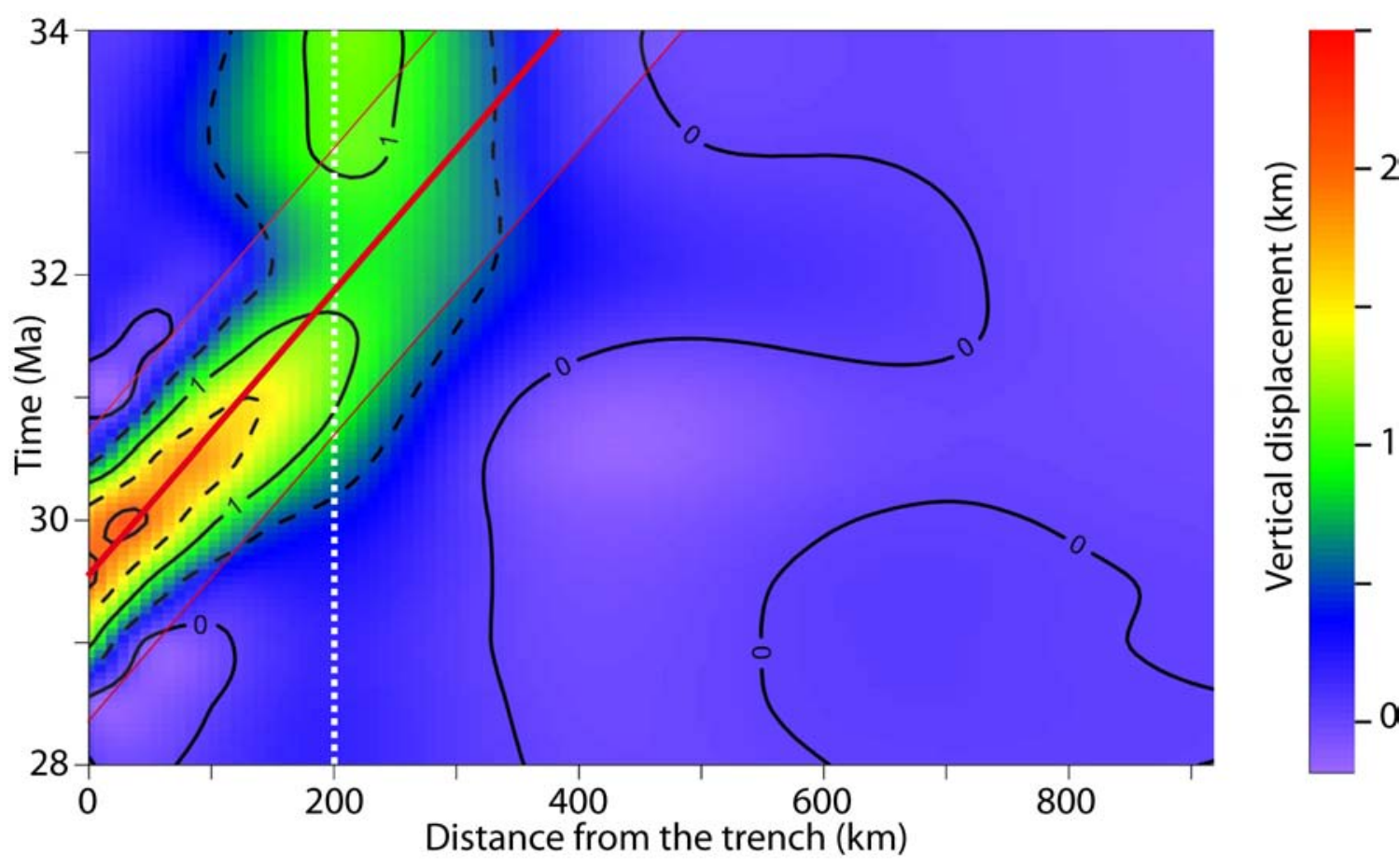

Figure 7: Vertical displacements of the overriding plate resulting from the subduction of a $3 \mathrm{~km}$-high bathymetric high (oceanic aseismic ridge). The ridge enters the trench at 28.5 Myrs. The dotted white line shows the position of the asthenosphere corner. Thin and thick oblique red lines mark the position of the borders and the axis, respectively, of the aseismic ridge, beneath the overriding plate. Uplift is transient in the forearc region. In contrast, it maintains following the subduction of the ridge in the arc and back-arc area.

Aseismic ridge subduction uplifts the forearc area. The uplifted zone migrates inland following the advance of the ridge beneath the continental plate. The maximum uplift is $\sim 2 \mathrm{~km}$ close to the trench, and $\sim 1 \mathrm{~km}$ above the asthenosphere corner. After the plateau has entirely been subducted within 
the asthenosphere, a permanent uplift close to $\sim 1 \mathrm{~km}$ maintains in the volcanic arc region, resulting from the deformation of the overriding plate during plateau subduction.

\section{Discussion}

The models presented above suggest that several changes in the dynamics of subduction may result in vertical surface displacements of the overriding plate. We focus our discussion on displacements observed along the Pacific coast, because (1) they are generally larger than in arc or back-arc regions (2) paleo-shores give precise information on forearc uplift, and (3) we do not model tectonic processes that exert a major control on crustal thickness, isostasy, and in turn on the elevation of the central part of the Andean orogen.

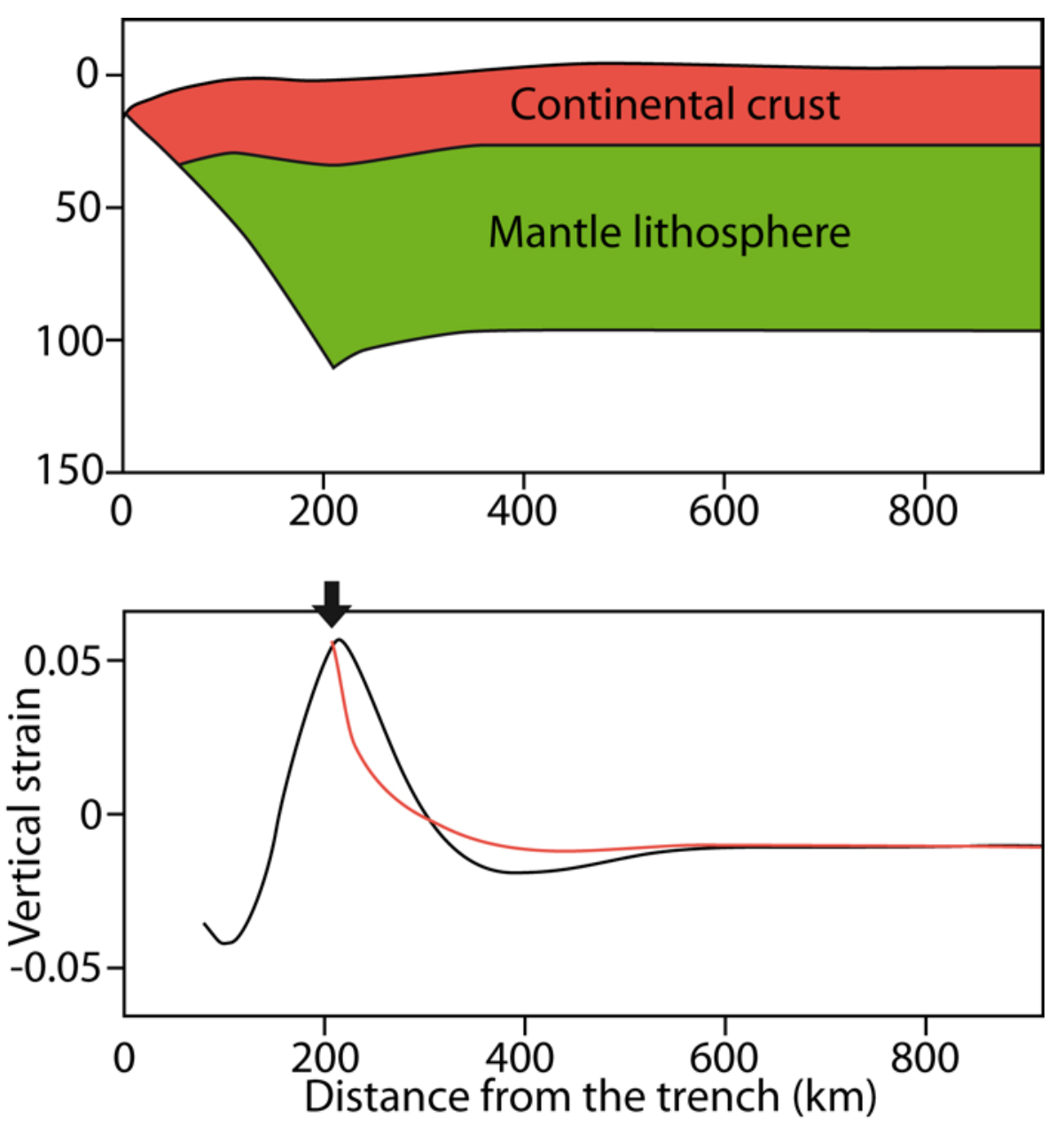

Figure 8: (a) cross-section of the continental plate in the reference experiment, following 28 Myrs of subduction, and (b) average vertical strain of the continental crust (black line) and of the whole plate (red line). Positive and negative strain corresponds to thickening and thinning, respectively. Note that

lithosphere thickening is larger above the asthenospheric corner (black arrow), as a result of the downward pull of the slab.

In this experimental set, the overriding plate is homogeneous, visco-elastic, and its viscosity is close to that of the subducting plate. Hence, the overriding plate deforms slowly. We observe that the resulting topography is not compensated by the thickening of the continental crust, but essentially results from the flexure of the overriding plate (Figure 8). The overriding continent is 
pulled downwards by the negative buoyancy of the subducting plate and, when the interplate friction is not zero, by the shear stress resulting from the subduction of the oceanic plate. Since we neglect the viscosity of the mantle asthenosphere in this experimental set, the two converging plates only interact beneath the forearc area where they touch themselves. The pull of the subducting plate being concentrated in the forearc area, vertical displacements in this part of the overriding plate are exaggerated, and we do not observe the long-wavelength deflections that characterize the dynamic topography resulting from the subduction of an oceanic plate (e.g., Mitrovica et al., 1989; Husson, 2006). Hampel and Pfiffner (2006) modeled the topographic evolution of the overriding plate during the initiation of subduction, following $200 \mathrm{~km}$ of slip on the plate interface. Their numerical models consider the viscosity of the upper mantle, but the viscosity ratio between lithospheric plates and upper mantle is very large (between $10^{5}$ and $10^{6}$ ), and they also observe that the lower part of overriding plate is essentially dragged down by the pull of the slab. Bonnardot et al. (2008) also look at the overriding plate topography during subduction initiation, following $600 \mathrm{~km}$ of plate convergence. They model the lithosphere as either elastic, or elasto-plastic plates. They show that increasing the viscosity of the asthenospheric wedge to $2.10^{20}$ Pa.s may diminish the downward deflection of the overriding plate above the lower segment of the interplate contact by a factor 3 or more, depending on the rheology of lithospheric plates. Note, however, that 2D-models by Bonnardot et al. (2008) do not allow trench-parallel flow in the upper mantle, which probably exaggerates the effects of mantle dynamics on the slab geometry as well as on the upper plate topography. Moreover, as explained above, quantifying the effect of a perturbation in the process of subduction on the upper plate topography is only possible if the subduction zone already reached a steady-state regime.

\begin{tabular}{|c|c|c|c|c|}
\hline \multicolumn{2}{|c|}{ Experiment } & Time (Myr) & Total uplift $(\mathrm{km})$ & Uplift rate $(\mathrm{mm} / \mathrm{yr})$ \\
\hline \multirow{3}{*}{ VEL-40 } & forearc & $0-5$ & 1.6 & 0.32 \\
\hline & arc & - & 0 & 0 \\
\hline & back-arc & $0-3$ & -0.7 & -0.23 \\
\hline \multirow{3}{*}{ VEL-120 } & forearc & $0-5$ & -1.2 & -0.24 \\
\hline & arc & - & 0 & 0 \\
\hline & back-arc & $0-3$ & 0.6 & 0.2 \\
\hline \multirow{3}{*}{ FRIC-0 } & forearc & $0-3 ; 3-7$ & $0.1 ; 0.4$ & $0.03 ; 0.08$ \\
\hline & arc & $0-3 ; 3-7$ & $0 ; 0.3$ & $0 ; 0.08$ \\
\hline & back-arc & & 0 & 0 \\
\hline \multirow{3}{*}{ FRIC-6 } & forearc & $0-1 ; 1-4$ & $-0.15 ;-0.1$ & $-0.15 ; 0.03$ \\
\hline & arc & $0-1 ; 1-2$ & $-0.15 ; 0$ & $-0.15 ; 0.15$ \\
\hline & back-arc & - & 0 & 0 \\
\hline \multirow{3}{*}{ AGE-25 } & forearc & $0-2$ & 2.5 & 1.2 \\
\hline & $\operatorname{arc}$ & - & 0 & 0 \\
\hline & back-arc & $0-3$ & -0.6 & -0.2 \\
\hline \multirow{3}{*}{ RIDGE } & forearc & $0.5-2 ; 2-3$ & $1.7 ; 0.2$ & $1.1 ;-1.3$ \\
\hline & arc & $1.5-3$ & 1 & 0.67 \\
\hline & back-arc & $2-3.5$ & $0: 0.5$ & 0.5 \\
\hline
\end{tabular}

Table 2: Uplift and vertical velocities of the surface of the overriding plate resulting from a perturbation in the process of subduction, measured $100 \mathrm{~km}$ (forearc area), $200 \mathrm{~km}$ (arc), and $300 \mathrm{~km}$ (back-arc) from the trench. Negative numbers mark subsidence. The time column indicates how long 
after the onset of perturbation uplift occurs. When the short-term effect differs from the longer-term effect, corresponding values are indicated separated by a semi-colon.

Despite the limitations of these calculations, we consider that they give first-order insights about the forearc tendency to uplift or subside when a perturbation is affecting the process of subduction. Table 2 compares the effects and magnitude of the different studied perturbations on the vertical displacements of the overriding plate. In the following, we further discuss the possible causes that may explain the vertical displacements of South America.

\subsection{Age and buoyancy of the subducting plate and steady-state hypothesis}

The age of the subducting plate and the pull exerted by the slab may explain vertical displacements of the overriding continent (e.g., Heuret et al., 2007). Although plates reconstruction by Sdrolias \& Muller (2006) show that the average age of the Nazca plate at trench was somewhat older 20 Myrs ago ( 45 vs. 35 Myrs-old today), the age of the subducting Nazca plate does not appear to have changed significantly during the last 10 Myrs. Experiment AGE-25 models the effect of a sudden diminution of the age of the subducting plate, and shows that most of the overriding plate forearc region uplift occurs less than 2 Myrs following the arrival of the young plate segment at trench if the convergence velocity is $80 \mathrm{~mm} / \mathrm{yr}$. This velocity being the order of magnitude of the Nazca-South America convergence rate since 10 Myrs (e.g., Somoza \& Ghidella, 2012), the age of the subducting plate does not explain the observed uplift in the Pacific coasts of South America.

Nevertheless, although the age of the subducting plate did not change significantly, the average buoyancy of the slab may have changed, as evidenced by the appearance of two major flat slab segments since the Late Miocene beneath Peru and Chile (Martinod et al., 2010). Perhaps more important, rapid changes in the dip of the slab highlight that the Nazca subduction zone is certainly not steady-state. Quinteros \& Sobolev (2013) note that the azimuth of plate convergence changed drastically 24 Myrs ago following the rupture of Farallon into Nazca and Cocos plates. Convergence along the Chilean Coasts, for instance, passed from nearly trench-parallel to nearly trenchperpendicular. Quinteros \& Sobolev (2013) propose that the change in the convergence azimuth, and the interaction of the slab with the upper-lower mantle boundary, may account for the changes in convergence velocity since the Early Miocene. Volcanic arc migrations, as for instance in the southern central Andes where the arc moved $\sim 200 \mathrm{~km}$ trenchward since the Pliocene (Folguera et al., 2006), is a clear evidence that the Nazca subduction zone is not steady-state. In fact, subduction zones may never reach any steady-state regime (Guillaume et al., 2009; Lee \& King, 2011). Then, if the steadystate hypothesis is useful to see the effects of perturbations on the subduction process and on the overriding plate topography, we do not pretend that the Nazca subduction zone is actually steady. Nevertheless, the numerical models presented above suggest other possible causes for the observed vertical displacements of the South American Pacific coasts.

\subsection{Effect of buoyant ridges}

Subducting buoyant aseismic ridges beneath South America have long been recognized to impact severely the observed coastal vertical displacements, as explained above in this paper. Model RIDGE shows the effect of an aseismic ridge whose dimension is close to that of the Nazca or Carnegie ridges. For instance, the width of the Nazca Ridge segment visible in the Pacific sea-floor is $300 \mathrm{~km}$ on 
average, vs. $200 \mathrm{~km}$ for the modeled ridge, and its axis is generally 1500 meters above the oceanic sea-floor, vs. 3000 meters in the numerical experiment. A major difference between calculations presented here and the Nazca Ridge subduction zone is that 2-D calculations model a subduction zone in which the subducting ridge is trench-parallel, whereas the Nazca ridge is oblique with respect to the trench. Numerical experiments show that coastal uplift has the same order of magnitude than the topography of the subducting plate, as already suggested by Moretti (1983) modeling the overriding plate as an elastic layer. $100 \mathrm{~km}$ from the trench, which generally corresponds to the location of the coastline, the maximum uplift we measure in our experiments is $1.7 \mathrm{~km}$ for the $3 \mathrm{~km}$ high ridge (Table 2). The maximum uplift observed above the Nazca ridge is $\sim 1 \mathrm{~km}$ (Macharé \& Ortlieb, 1992), i.e. the ratio between uplift and ridge seafloor topography is comparable in nature and experiment. Experiments also show that the forearc uplift resulting from the subduction of an aseismic ridge is transient. Once the ridge has been subducted, the forearc recovers again the same elevation than before ridge subduction.

Table 2 shows that ridge subduction may result in forearc uplift velocities faster than $1 \mathrm{~mm} / \mathrm{yr}$, largely exceeding those resulting from a change in either convergence velocity or interplate friction. Dynamics of coastal segments in central Peru confirm that the subduction and southward lateral migration of the Nazca ridge is the first-order parameter that constrains the vertical displacements in this part of South America. Indeed, subsidence is observed on the northern flank of the ridge, while rapid uplift is observed above and south the Nazca Ridge axis (Punta Caiman, 14.6 ${ }^{\circ} \mathrm{S}$; Hsu, 1992; Machare \& Ortlieb, 1992). Saillard et al. (2011) confirm that the effect of the Nazca Ridge is noticeable in the forearc zone more than $300 \mathrm{~km}$ from the ridge axis. They also show, however, that the coastal uplift observed in San Juan de Marcona $\left(15.4^{\circ} \mathrm{S}\right)$ is faster than the uplift rate expected from the southward migration of the Nazca Ridge alone. In San Juan de Marcona, indeed, considering the southward migration velocity of the ridge $(43 \mathrm{~mm} / \mathrm{yr})$ and the mean ridge slope $\left(0.55^{\circ}\right)$, the uplift rate would be $0.41 \mathrm{~mm} / \mathrm{yr}$ considering $1 \mathrm{D}$ isostatic compensation (i.e. supposing that the forearc uplift corresponds to the ridge topography subducted beneath the continent). In the presented model (RIDGE), the forearc uplift $100 \mathrm{~km}$ from the trench is only half the ridge topography. The very fast ( $0.55 \mathrm{~mm} / \mathrm{yr}$ ) uplift rate measured in San Juan de Marcona by Saillard et al. (2011) shows that although the subduction of the Nazca Ridge largely controls coastal vertical displacements in Peru, another phenomenon than ridge subduction is responsible for the velocity of coastal uplift.

We also observe that ridge subduction may significantly uplift the volcanic arc area itself: uplift resulting from the subduction of the ridge is $\sim 1 \mathrm{~km}$ above the asthenosphere corner, suggesting that the subduction of the Nazca ridge may also result in vertical displacements of the present-day volcanic arc region (Western Cordillera). Some uplift also occurs in the back-arc region, as observed in the western Amazonian Basin above the subduction of the Nazca (Espurt et al., 2007) and Carnegie ridges (Christophoul et al., 2002). Back-arc uplift initiates 2 Myrs following the beginning of ridge subduction for a $80 \mathrm{~mm} / \mathrm{yr}$ convergence velocity (Table 2). Then, considering an average convergence velocity of $68 \mathrm{~mm} / \mathrm{yr}$, uplift in the back-arc region of Ecuador implies that the Carnegie Ridge is subducting at least since $2.5 \mathrm{Myrs}$, which is more than the minimum age proposed in the literature but is in agreement with geological and geophysical constraints (Michaud et al., 2009). The main difference between forearc uplift on the one hand, arc and back-arc uplift on the other hand, is that the former is transient and corresponds to isostatic adjustments accommodating ridge subduction, while the latter is permanent because ridge subduction has been accommodated by the thickening of the continental lithosphere in the arc region. 


\subsection{Changing interplate stresses}

Yañez \& Cembrano (2004) propose that the dynamic topography of the trench and forearc domain is basically controlled by the convergence velocity and interplate forces. Models presented above confirm that a diminution of the slab pull force, but also a diminution of the interplate friction and a decrease of the convergence velocity may result in coastal uplift. Interplate friction may depend on the amount of sediment arriving at trench which, in turn, depends on climate. Lamb \& Davis (2003) propose that climate-controlled sediment starvation in the trench of the Central Andes increases the interplate friction, which results in large plate boundary stresses favoring the growth of the chain. Then, a larger amount of sediment reaching the trench may decrease the interplate friction and, in turn, promote coastal uplift. However, trench starvation in sediment between 12 and $26^{\circ} \mathrm{S}$ results from the climate of the Atacama Desert that maintained hyper-arid since the Late Miocene (Alpers \& Brimhall, 1988; Dunai et al., 2005). Thus, sediments at the trench do not explain uplift initiating in the Middle Pleistocene. Moreover, uplift is also observed in Southern Chile till $40^{\circ} \mathrm{S}$, where the climate is very humid. Then, it is difficult to imagine a climatic cause to explain an uplift observed in these completely different climatic conditions.

Pedoja et al. (2011) proposed that coastal uplift may result from an increase of worldwide mean compressional stresses. This increase could be the consequence of the current accretion of India, Africa and Australia to the Eurasian plate. These authors propose that increasing compression may result in moderate coastal uplift close to passive margins, and faster uplift above subduction zones. Numerical models presented above, however, do not support the idea that an increase in the compression regime may cause coastal uplift along active margins. They suggest instead that a stronger interplate contact results in the downward deflection of the overriding plate, i.e. in coastal subsidence.

Finally, the observed maximum uplift is smaller than 500 meters in the forearc region when the interplate friction coefficient suddenly drops from 0.03 to zero, and the corresponding uplift velocity is smaller than $0.1 \mathrm{~mm} / \mathrm{yr}$. Although little is known on the strength of the subduction channel, such a dramatic stress drop on the interplate contact is difficult to imagine, suggesting that changes in the interplate friction do not explain the present-day coastal uplift in South America.

\subsection{Variation of the convergence velocity}

Models suggest that variations in convergence velocity may result in larger vertical displacements than those resulting from changes in the interplate friction (Table 2). Indeed, the calculated order of magnitude of vertical upward or downward deflections of the forearc region is $1.4 \mathrm{~km}$ following a 4 $\mathrm{cm} / \mathrm{yr}$ decrease or increase, respectively, of the convergence velocity. The corresponding uplift or subsidence velocity approaches $0.3 \mathrm{~mm} / \mathrm{yr}$. This value is close to the average uplift velocity observed on the coasts of South America for the Upper Pleistocene. Note that in the numerical experiments presented above, we consider that the interplate friction does not depend on the convergence velocity, whereas a decrease in convergence velocity may be accompanied by a variation of the interplate stresses, in particular because the rheology of the subduction channel is partly viscous and strain-rate dependent (e.g., Reynard, 2013). In case a diminution of the convergence velocity is accompanied by a diminution of the interplate friction, this would further favor coastal uplift. 
The convergence velocity between the oceanic plate and South America has been decreasing since the Early Miocene from 150 to 66 mm/yr (Pardo-Casas \& Molnar, 1987; Somoza, 1998; Somoza \& Ghidella, 2012). DeMets et al. (2010) observe that the convergence velocity decreased rapidly for 3 Myrs, as evidenced comparing the Nuvel-1a, Morvel and Geodvel models. They note that the largest change in plate kinematics that occurred in that period of time concerns the Nazca-South America plate boundary. The convergence velocity estimated at $22^{\circ} \mathrm{S}$ by the Nuvel-1a model is $79.5 \mathrm{~mm} / \mathrm{yr}$ (DeMets et al., 1994). This velocity has been estimated from the mapping of magnetic anomalies in oceanic sea-floor and corresponds to the average convergence velocity for $3.16 \mathrm{Myrs}$. The Morvel model estimates plate's motion averaged for the 0.78 last Myrs (since the Brunhes-Matuyama geomagnetic reversal). The Nazca-South America convergence velocity estimated by the Morvel model is $6.5 \mathrm{~mm} / \mathrm{yr}$ smaller than predicted by Nuvel-1a (deMets et al., 2010). It is also, however, 6.5 $\mathrm{mm} / \mathrm{yr}$ faster than the present-day convergence velocity estimated using geodetic data (Geodvel model), suggesting that the convergence slow down registered since 3 Myrs mostly occurred during the Middle and Upper Pleistocene. A possible scenario supposing a unique sudden change in plate's kinematics to explain discrepancies between Nuvel-1a, Morvel and Geodvel models would require a $15 \mathrm{~mm} / \mathrm{yr}, 0.45 \mathrm{Myr}$-old, diminution of the convergence velocity between the Nazca and South America plates. Although such a theoretical scenario probably does not correspond to the exact plate convergence time-history, the significant diminution of the convergence velocity during the last Myr suggested by these models may explain part of the observed uplift.

\subsection{Did variations in convergence velocity control the history of vertical forearc displacements in South America?}

Models show that a diminution in the convergence velocity results in the uplift of the entire forearc region, from the trench to the volcanic arc. In contrast, increasing convergence velocity favors forearc subsidence. Miocene subsidence has been widely described along the South American active margin, both in Peru (e.g., Hussong et al., 1978; von Huene \& Scholl, 1991), northern (Marquardt, 2005; Le Roux et al., 2005) and southern Chile (Encinas et al., 2013). Although subsidence is not always precisely dated, and although it is not clear that it is everywhere synchronous along the margin (see Encinas et al., 2013, for discussion), the base of Miocene deposits is generally discordant above Cretaceous to Paleogene rocks. Miocene deposits often fill incised paleotopographies, suggesting that this subsidence followed a period of forearc uplift and erosion (Paskoff, 1970; Marquardt, 1999; Rodriguez et al., 2013). We thus propose that the Miocene subsidence may have resulted from the acceleration of plate convergence following the rupture of Farallon and the appearance of the Nazca plate, while the Oligocene forearc erosion may have resulted from a low convergence rate at that time.

The same analysis may be extended elsewhere and/or to older time periods. Jaillard \& Soler (1996) note that periods of increased and decreased subsidence rates in Peru coincide with high and low convergence velocities, respectively, during the Upper Cretaceous and Paleogene. However, their data suggest that fast convergence related subsidence also concerns the back-arc area. This is not observed in these models, probably because we neglected the upper mantle viscosity, which transmits the downward pull exerted by the slab on the back-arc region (see above). In the margin of North-East Japan, Regalla et al. (2013) also observe a tendency to forearc subsidence during periods of increasing convergence velocities. 
Of course, many other processes may also trigger forearc subsidence or uplift. Locally, the subduction of seafloor anomalies such as the subduction of a large oceanic plateau beneath the Central Andes in the Eocene-Oligocene period (e.g., Martinod et al., 2010) may have severely impacted the forearc elevation. It is also clear, as explained above, that the Nazca Ridge subduction is the first-order phenomenon explaining the present-day forearc vertical displacements in central Peru, and that displacements arising from this ridge subduction largely mask those resulting from other geodynamical changes such as the change in convergence velocity. Tectonic erosion has also been proposed to explain forearc subsidence in Japan and Peru (von Huene \& Lallemand, 1990). Regalla et al. (2013), however, note that tectonic erosion does not explain many characteristics of the subsidence pattern observed in Japan. In particular, they argue that tectonic erosion should concentrate close to the trench, because beneath the coastline and onshore, tectonic erosion removing mantle lithosphere should not induce subsidence. Finally, they note that periods of tectonic erosion should alternate with periods of tectonic accretion to explain the shift from subsidence to uplift. Intraplate forearc seismicity at the base of the overriding plate that may accompany tectonic accretion has only been reported in particular areas of South America such as the Arauco Peninsula (Melnick et al., 2006). There, indeed, coastal surface uplift is locally very rapid, exceeding $1 \mathrm{~mm} / \mathrm{yr}$. Of course, forearc tectonics may have been different in the past history of South America, and further work is necessary to constrain the causes of the subsidence reported by von Huene \& Lallemand (1990) offshore Peru. Tectonic accretion being now restricted to narrow segments of the South American coast, we propose that a dynamic control exerted by the subducting plate on the overriding forearc explains part of the observed uplift or subsidence, during convergence velocity decrease or increase, respectively. This mechanism may combine with other causes, such as the tectonic erosion/accretion phenomenon proposed by von Huene \& Lallemand (1990), in controlling alternating periods of uplift and subsidence of the Andean forearc.

\section{Conclusion}

Preserved paleoshores along the Pacific Coast of South America reveal that most segments of the Andean forearc have been uplifting since the Middle Pleistocene at rates larger than $0.2 \mathrm{~mm} / \mathrm{yr}$. If local perturbations of the subduction process resulting either from the arrival at trench of buoyant ridges, or from subduction erosion and accretion, may result in local uplift or subsidence of the coasts, they do not explain the general tendency to coastal uplift, which contrasts with the stability or subsidence that generally prevailed before the Middle Pleistocene (e.g., Paskoff, 1978; Clift \& Hartley, 2007; Rodriguez et al., 2013). We presented numerical models to study how changes in the dynamics of subduction affect the surface displacements of the overriding plate. Models show that forearc vertical displacements resulting from changes in the dynamics of subduction may differ from those occurring elsewhere in the continent (arc and back-arc area). They confirm that buoyant anomalies in the oceanic plate exert a first-order control on the vertical forearc displacements when they are subducted. Models also suggest that flexural deformation of the overriding lithosphere may result from changes in the dynamics of subduction. In particular, forearc surface uplift is shown to depend on variations in convergence velocity. We propose that the Pleistocene diminution of the Nazca-South America convergence velocity may result in the generalized uplift observed along the coasts of South America. 
Acknowledgments: We thank the INSU (Institut National des Sciences de I'Univers, France) program "Reliefs de la Terre » and ECOS-Conicyt for financial support. Many thanks also to the editor W. Schellart, guest editor Y. Rolland, and two anonymous reviewers for their comments.

\section{References:}

Alpers, C., and Brimhall, G. (1988). Middle Miocene Climatic-Change in the Atacama Desert, Northern Chile - Evidence from Supergene Mineralization at La-Escondida. Geol. Soc. Am. Bull. 100, 1640-1656.

Bonnardot, M.-A., Hassani, R., and Tric, E. (2008). Numerical modelling of lithosphere-asthenosphere interaction in a subduction zone. Earth Planet. Sci. Lett. 272, 698-708.

Chéry, J., Zoback, M.D., and Hassani, R. (2001). An integrated mechanical model of the San Andreas fault in central and northern California. J. Geophys. Res.-Solid Earth 106, 22051-22066.

Christensen, U.R. (1996). The influence of trench migration on slab penetration into the lower mantle. Earth Planet. Sci. Lett. 140, 27-39.

Christophoul, F., Baby, P., Soula, J.C., Rosero, M., and Burgos, J. (2002). The Neogene fluvial systems of the Ecuadorian foreland basin and dynamic inferences. C. R. Geosci. 334, 1029-1037.

Clift, P.D., and Hartley, A.J. (2007). Slow rates of subduction erosion and coastal underplating along the Andean margin of Chile and Peru. Geology 35, 503-506.

Cloos, M. (1993). Lithospheric Buoyancy and Collisional Orogenesis - Subduction of Oceanic Plateaus, Continental Margins, Island Arcs, Spreading Ridges, and Seamounts. Geol. Soc. Am. Bull. 105, 715-737.

Coira, B., Davidson, J., Mpodozis, C., and Ramos, V. (1982). Tectonic and Magmatic Evolution of the Andes of Northern Argentina and Chile. Earth-Sci. Rev. 18, 303-332.

Cortes-Aranda, J., Gonzalez, G., Remy, D., and Martinod, J. (2015). Normal upper plate fault reactivation in northern Chile and the subduction earthquake cycle: From geological observations and static Coulomb Failure Stress (CFS) change. Tectonophysics 639, 118-131.

Cundall, P. (1988). Formulation of a 3-Dimensional Distinct Element Model .1. a Scheme to Detect and Represent Contacts in a System Composed of Many Polyhedral Blocks. Int. J. Rock Mech. Min. Sci. 25, 107-116.

Darwin, C.R. (1846). Voyage of a naturalist, or journal of researches into the natural history and geology of the countries visited during the voyage of $\mathrm{H}$. M. S. Beagle round the world, under the command of Capt. Fitz Roy, R. N (Harper and Brothers : New York, NY, United States).

DeMets, C., Gordon, R., Argus, D., and Stein, S. (1994). Effect of Recent Revisions to the Geomagnetic Reversal Time-Scale on Estimates of Current Plate Motions. Geophys. Res. Lett. 21, 2191-2194.

DeMets, C., Gordon, R.G., and Argus, D.F. (2010). Geologically current plate motions. Geophys. J. Int. 181, 1-80.

Dunai, T.J., Lopez, G.A.G., and Juez-Larre, J. (2005). Oligocene-Miocene age of aridity in the Atacama Desert revealed by exposure dating of erosion-sensitive landforms. Geology 33, 321-324.

Encinas, A., Zambrano, P.A., Finger, K.L., Valencia, V., Buatois, L.A., and Duhart, P. (2013). Implications of Deep-Marine Miocene Deposits on the Evolution of the North Patagonian Andes. J. Geol. 121, 215-238.

Espurt, N., Baby, P., Brusset, S., Rodaz, M., Hermoza, W., Regard, V., Antoine, P.O., Salas-Gismondi, R., and Bolanos, R. (2007). How does the Nazca Ridge subduction influence the modern Amazonian foreland basin? Geology 35, 515-518.

Espurt, N., Funiciello, F., Martinod, J., Guillaume, B., Regard, V., Faccenna, C., and Brusset, S. (2008). Flat subduction dynamics and deformation of the South American plate: Insights from analog modeling. Tectonics 27, TC3011, doi: 10.1029/2007TC002175.

Faccenna, C., Becker, T.W., Lucente, F.P., Jolivet, L., and Rossetti, F. (2001). History of subduction and back-arc extension in the Central Mediterranean. Geophys. J. Int. 145, 809-820.

Farias, M., Vargas, G., Tassara, A., Carretier, S., Baize, S., Melnick, D., and Bataille, K. (2010). Land-Level Changes Produced 
by the M-w 8.82010 Chilean Earthquake. Science 329, 916-916.

Folguera, A., Zapata, T., and Ramos, V.A. (2006). Late Cenozoic extension and the evolution of the Neuquen Andes. Special Paper - Geological Society of America 407, 267-285.

Fuenzalida, H., Cooke, R., Paskoff, R., Segerstrom, K., and Weischet, W. (1965). High Stands of Quaternary Sea Level Along the Chilean Coast. In Geological Society of America Special Papers, (Geological Society of America), pp. 473-496.

Funiciello, F., Moroni, M., Piromallo, C., Faccenna, C., Cenedese, A., and Bui, H.A. (2006). Mapping mantle flow during retreating subduction: Laboratory models analyzed by feature tracking. J. Geophys. Res.-Solid Earth 111, B03402, doi: 10.1029/2005JB003792.

Funiciello, F., Faccenna, C., Heuret, A., Lallemand, S., Di Giuseppe, E., and Becker, T.W. (2008). Trench migration, net rotation and slab-mantle coupling. Earth Planet. Sci. Lett. 271, 233-240.

Gibert, G., Gerbault, M., Hassani, R., and Tric, E. (2012). Dependency of slab geometry on absolute velocities and conditions for cyclicity: insights from numerical modelling. Geophys. J. Int. 189, 747-760.

Gonzalez, G., Cembrano, J., Carrizo, D., Macci, A., and Schneider, H. (2003). The link between forearc tectonics and pliocene-quaternary deformation of the Coastal Cordillera, northern Chile. J. South Am. Earth Sci. 16, 321-342.

Got, J.-L., Monteiller, V., Monteux, J., Hassani, R., and Okubo, P. (2008). Deformation and rupture of the oceanic crust may control growth of Hawaiian volcanoes. Nature 451, 453-456.

Goy, J., Macharé, J., Ortlieb, L., and Zazo, C. (1992). Quaternary shorelines in southern Peru: A record of global sea-level fluctuations and tectonic uplift in Chala Bay. Quaternary International 15-16, 99-112.

Guillaume, B., Martinod, J., and Espurt, N. (2009). Variations of slab dip and overriding plate tectonics during subduction: Insights from analogue modelling. Tectonophysics 463, 167-174.

Guillaume, B., Funiciello, F., Faccenna, C., Martinod, J., and Olivetti, V. (2010). Spreading pulses of the Tyrrhenian Sea during the narrowing of the Calabrian slab. Geology 38, 819-822.

Gutscher, M.A., Malavieille, J., Lallemand, S., and Collot, J.Y. (1999). Tectonic segmentation of the North Andean margin: impact of the Carnegie Ridge collision. Earth Planet. Sci. Lett. 168, 255-270.

Hampel, A. (2002). The migration history of the Nazca Ridge along the Peruvian active margin: a re-evaluation. Earth Planet. Sci. Lett. 203, 665-679.

Hampel, A., and Pfiffner, A. (2006). Relative Importance of Trenchward Upper Plate Motion and Friction along the Plate Interface for the Topographic Evolution of Subduction-Related Mountain Belts. in: Analogue and Numerical Modelling of Crustal-Scale Processes, edited by: Buiter, S. J. H. and Schreurs, G., Geol. Soc. London Spec. Publ., 253, 105-115.

Hassani, R., Jongmans, D., and Chéry, J. (1997). Study of plate deformation and stress in subduction processes using twodimensional numerical models. J. Geophys. Res.-Solid Earth 102, 17951-17965.

Henry, H., Regard, V., Pedoja, K., Husson, L., Martinod, J., Witt, C., and Heuret, A. (2014). Upper Pleistocene uplifted shorelines as tracers of (local rather than global) subduction dynamics. J. Geodyn. 78, 8-20.

Heuret, A., Funiciello, F., Faccenna, C., and Lallemand, S. (2007). Plate kinematics, slab shape and back-arc stress: A comparison between laboratory models and current subduction zones. Earth Planet. Sci. Lett. 256, 473-483.

Hsu, J.T. (1992). Quaternary uplift of the peruvian coast related to the subduction of the Nazca Ridge: 13.5 to 15.6 degrees south latitude. Quaternary International 15-16, 87-97.

Husson, L. (2006). Dynamic topography above retreating subduction zones. Geology 34, 741-744.

Husson, L. (2012). Trench migration and upper plate strain over a convecting mantle. Phys. Earth Planet. Inter. 212, 32-43.

Hussong, D., and Wipperman, L. (1981). Vertical Movement and Tectonic Erosion of the Continental Wall of the Peru-Chile Trench Near 11-Degrees-30's Latitude. Geological Society of America Memoirs 154, 509-524.

Irvine, D.N., and Schellart, W.P. (2012). Effect of plate thickness on bending radius and energy dissipation at the subduction zone hinge. J. Geophys. Res.-Solid Earth 117, B06405, doi: 10.1029/2011JB009113.

Jaillard, E., and Soler, P. (1996). Cretaceous to early Paleogene tectonic evolution of the northern Central Andes (0-18 degrees S) and its relations to geodynamics. Tectonophysics 259, 41-53. 
Kohlstedt, D., Evans, B., and Mackwell, S. (1995). Strength of the Lithosphere - Constraints Imposed by Laboratory Experiments. J. Geophys. Res.-Solid Earth 100, 17587-17602.

Kopp, R.E., Simons, F.J., Mitrovica, J.X., Maloof, A.C., and Oppenheimer, M. (2009). Probabilistic assessment of sea level during the last interglacial stage. Nature 462, 863-U51.

Lamb, S., and Davis, P. (2003). Cenozoic climate change as a possible cause for the rise of the Andes. Nature 425, $792-797$.

Le Roux, J.P., Correa, C.T., and Alayza, F. (2000). Sedimentology of the Rimac-Chillon alluvial fan at Lime, Peru, as related to Plio-Pleistocene sea-level changes, glacial cycles and tectonics. J. South Am. Earth Sci. 13, 499-510.

Le Roux, J.P., Gomez, C., Venegas, C., Fenner, J., Middleton, H., Marchant, M., Buchbinder, B., Frassinetti, D., Marquardt, C., Gregory-Wodzicki, K.M., et al. (2005). Neogene-Quaternary coastal and offshore sedimentation in north central Chile: Record of sea-level changes and implications for Andean tectonism. J. South Am. Earth Sci. 19, 83-98.

Lee, C., and King, S.D. (2011). Dynamic buckling of subducting slabs reconciles geological and geophysical observations. Earth Planet. Sci. Lett. 312, 360-370.

Leonard, E., and Wehmiller, J. (1992). Low Uplift Rates and Terrace Reoccupation Inferred from Mollusk Aminostratigraphy, Coquimbo Bay Area, Chile. Quat. Res. 38, 246-259.

Lesne, O., Calais, E., Deverchère, J., Chéry, J., and Hassani, R. (2000). Dynamics of intracontinental extension in the north Baikal rift from two-dimensional numerical deformation modeling. J. Geophys. Res.-Solid Earth 105, 21727-21744.

Liu, K.H., Gao, S.S., Silver, P.G., and Zhang, Y. (2003). Mantle layering across central South America. Journal of Geophysical Research: Solid Earth 108, doi: 10.1029/2002JB002208.

Macharé, J., and Ortlieb, L. (1992). Plioquaternary Vertical Motions and the Subduction of the Nazca Ridge, Central Coast of Peru. Tectonophysics 205, 97-108.

Marquardt, C. (1999). Neotectonica de la franja costera y aportes a la geologia regional entre Caldera y Caleta Pajonal $\left(27^{\circ}-\right.$ $\left.27^{\circ} 45^{\prime} \mathrm{S}\right)$, tercera region de Atacama. Magister thesis. Universidad de Chile.

Marquardt, C. (2005). Déformations néogènes le long de la côte nord du Chili $\left(23^{\circ}-27^{\circ} \mathrm{S}\right)$, avant-arc des Andes centrales, PhD thesis, Toulouse 3 University.

Martinod, J., Funiciello, F., Faccenna, C., Labanieh, S., and Regard, V. (2005). Dynamical effects of subducting ridges: insights from 3-D laboratory models. Geophys. J. Int. 163, 1137-1150.

Martinod, J., Husson, L., Roperch, P., Guillaume, B., and Espurt, N. (2010). Horizontal subduction zones, convergence velocity and the building of the Andes. Earth Planet. Sci. Lett. 299, 299-309.

Melnick, D., Bookhagen, B., Echtler, H.P., and Strecker, M.R. (2006). Coastal deformation and great subduction earthquakes, Isla Santa María, Chile ( $\left.37^{\circ} \mathrm{S}\right)$. Geological Society of America Bulletin 118, 1463-1480.

Melnick, D., Bookhagen, B., Strecker, M.R., and Echtler, H.P. (2009). Segmentation of megathrust rupture zones from forearc deformation patterns over hundreds to millions of years, Arauco Peninsula, Chile. Journal of Geophysical Research 114, doi: 10.1029/2008JB005788.

Métois, M., Socquet, A., and Vigny, C. (2012). Interseismic coupling, segmentation and mechanical behavior of the central Chile subduction zone. J. Geophys. Res. 117, B03406, doi: 10.1029/2011JB008736.

Michaud, F., Witt, C., and Royer, J.Y. (2009). Influence of the subduction of the Carnegie volcanic ridge on Ecuadorian geology: Reality and fiction. Geol. Soc. Am. Mem. 204, 217-228.

Mitrovica, J.X., Beaumont, C., and Jarvis, G.T. (1989). Tilting of continental interiors by the dynamical effects of subduction. Tectonics 8, 1079-1094.

Moretti, I. (1983). Subduction des rides aséismiques. Thèse de 3e cycle.

Neves, S.P., Tommasi, A., Vauchez, A., and Hassani, R. (2008). Intraplate continental deformation: Influence of a heatproducing layer in the lithospheric mantle. Earth Planet. Sci. Lett. 274, 392-400.

Nocquet, J.-M., Villegas-Lanza, J.C., Chlieh, M., Mothes, P.A., Rolandone, F., Jarrin, P., Cisneros, D., Alvarado, A., Audin, L., Bondoux, F., et al. (2014). Motion of continental slivers and creeping subduction in the northern Andes. Nat. Geosci. 7, 287-291. 
Ortlieb, L., Zazo, C., Goy, J.L., HillaireMarcel, C., Ghaleb, B., and Cournoyer, L. (1996). Coastal deformation and sea-level changes in the northern Chile subduction area (23 degrees S) during the last 330 ky. Quat. Sci. Rev. 15, 819-831.

Pardo Casas, F., and Molnar, P. (1987). Relative Motion of the Nazca (farallon) and South-American Plates Since Late Cretaceous Time. Tectonics 6, 233-248.

Paskoff, R. (1970). Recherches géomorphologiques dans le Chili semi-aride, Biscaye frères ed., Bordeaux, 420 pp.

Paskoff, R. (1978). Sur l'évolution géomorphologique du grand escarpement côtier du désert chilien. Géographie Physique et Quaternaire 32, 351.

Pédoja, K., Dumont, J.F., Lamothe, M., Ortlieb, L., Collot, J.-Y., Ghaleb, B., Auclair, M., Alvarez, V., and Labrousse, B. (2006). Plio-Quaternary uplift of the Manta Peninsula and La Plata Island and the subduction of the Carnegie Ridge, central coast of Ecuador. J. South Am. Earth Sci. 22, 1-21.

Pédoja, K., Husson, L., Regard, V., Cobbold, P.R., Ostanciaux, E., Johnson, M.E., Kershaw, S., Saillard, M., Martinod, J., Furgerot, L., et al. (2011). Relative sea-level fall since the last interglacial stage: Are coasts uplifting worldwide? EarthSci. Rev. 108, 1-15.

Poliakov, A., and Podladchikov, Y. (1992). Diapirism and Topography. Geophys. J. Int. 109, 553-564.

Quinteros, J., and Sobolev, S.V. (2013). Why has the Nazca plate slowed since the Neogene? Geology 41, 31-34.

Regalla, C., Fisher, D.M., Kirby, E., and Furlong, K.P. (2013). Relationship between outer forearc subsidence and plate boundary kinematics along the Northeast Japan convergent margin. Geochemistry, Geophysics, Geosystems, doi: 10.1002/2013GC005008.

Regard, V., Saillard, M., Martinod, J., Audin, L., Carretier, S., Pedoja, K., Riquelme, R., Paredes, P., and Hérail, G. (2010). Renewed uplift of the Central Andes Forearc revealed by coastal evolution during the Quaternary. Earth Planet. Sci. Lett. 297, 199-210.

Reynard, B. (2013). Serpentine in active subduction zones. Lithos 178, 171-185.

Ribe, N.M. (2010). Bending mechanics and mode selection in free subduction: a thin-sheet analysis. Geophys. J. Int. 180, 559-576.

Rodriguez, M.P., Carretier, S., Charrier, R., Saillard, M., Regard, V., Hérail, G., Hall, S., Farber, D., and Audin, L. (2013). Geochronology of pediments and marine terraces in north-central Chile and their implications for Quaternary uplift in the Western Andes. Geomorphology 180, 33-46.

Saillard, M., Hall, S.R., Audin, L., Farber, D.L., Martinod, J., Regard, V., Pedoja, K., and Hérail, G. (2010). Reply to a Comment on "Non-steady long-term uplift rates and Pleistocene marine terrace development along the Andean margin of Chile (31 degrees S) inferred from Be-10 dating" . Earth Planet. Sci. Lett. 296, 506-509.

Saillard, M., Hall, S.R., Audin, L., Farber, D.L., Regard, V., and Hérail, G. (2011). Andean coastal uplift and active tectonics in southern Peru: Be-10 surface exposure dating of differentially uplifted marine terrace sequences (San Juan de Marcona, similar to 15.4 degrees S). Geomorphology 128, 178-190.

Schellart, W.P. (2008). Kinematics and flow patterns in deep mantle and upper mantle subduction models: Influence of the mantle depth and slab to mantle viscosity ratio. Geochem. Geophys. Geosyst. 9, Q03014.

Schellart, W.P., Freeman, J., Stegman, D.R., Moresi, L., and May, D. (2007). Evolution and diversity of subduction zones controlled by slab width. Nature $446,308-311$.

Sdrolias, M., and Muller, R.D. (2006). Controls on back-arc basin formation. Geochem. Geophys. Geosyst. 7, Q04016.

Siddall, M., Chappell, J., and Potter, E.-K. (2007). 7. Eustatic sea level during past interglacials. In Developments in Quaternary Sciences, M.C., María Fernanda Sánchez Goñi and Thomas Litt Frank Sirocko, ed. (Elsevier), pp. 75-92.

Somoza, R. (1998). Updated Nazca (Farallon) - South America relative motions during the last 40 My: implications for mountain building in the central Andean region. J. South Am. Earth Sci. 11, 211-215.

Somoza, R., and Ghidella, M.E. (2012). Late Cretaceous to recent plate motions in western South America revisited. Earth Planet. Sci. Lett. 331, 152-163.

Vanbrabant, Y., Jongmans, D., Hassani, R., and Bellino, D. (1999). An application of two-dimensional finite-element 
modelling for studying the deformation of the Variscan fold-and-thrust belt (Belgium). Tectonophysics 309, 141-159.

Van der Hist, R., Engdahl, R., Spakman, W., and Nolet, G. (1991). Tomographic imaging of subducted lithosphere below northwest Pacific island arcs. Nature 353, 37-43.

Victor, P., Sobiesiak, M., Glodny, J., Nielsen, S.N., and Oncken, O. (2011). Long-term persistence of subduction earthquake segment boundaries: Evidence from Mejillones Peninsula, northern Chile. J. Geophys. Res.-Solid Earth 116, B02402, doi: 10.1029/2010JB007771.

Vigny, C., Socquet, A., Peyrat, S., Ruegg, J.-C., Metois, M., Madariaga, R., Morvan, S., Lancieri, M., Lacassin, R., Campos, J., et al. (2011). The 2010 M-w 8.8 Maule Megathrust Earthquake of Central Chile, Monitored by GPS. Science 332, 14171421.

Von Huene, R., and Lallemand, S. (1990). Tectonic Erosion along the Japan and Peru Convergent Margins. Geol. Soc. Am. Bull. 102, 704-720.

Von Huene, R., and Scholl, D.W. (1991). Observations at Convergent Margins Concerning Sediment Subduction, Subduction Erosion, and the Growth of Continental-Crust. Rev. Geophys. 29, 279-316.

Wipf, M., Zeilinger, G., Seward, D., and Schlunegger, F. (2008). Focused subaerial erosion during ridge subduction: impact on the geomorphology in south-central Peru. Terra Nova 20, 1-10.

Yañez, G., and Cembrano, J. (2004). Role of viscous plate coupling in the late Tertiary Andean tectonics. J. Geophys. Res.Solid Earth 109, B02407.

Yañez, G.A., Ranero, C.R., von Huene, R., and Diaz, J. (2001). Magnetic anomaly interpretation across the southern central Andes (32 degrees-34 degrees S): The role of the Juan Fernandez Ridge in the late Tertiary evolution of the margin. J. Geophys. Res.-Solid Earth 106, 6325-6345.

Zhong, S., and Gurnis, M. (1994). Controls on Trench Topography from Dynamic-Models of Subducted Slabs. J. Geophys. Res.-Solid Earth 99, 15683-15695. 